\title{
Genomic and functional characterization of StCDPK1
}

\author{
Pablo Rubén Gargantini · Verónica Giammaria · \\ Carolina Grandellis · Sergio E. Feingold · \\ Sara Maldonado · Rita María Ulloa
}

Received: 30 May 2008/ Accepted: 21 January 2009

(C) Springer Science+Business Media B.V. 2009

\begin{abstract}
StCDPK1 is a calcium dependent protein kinase expressed in tuberizing potato stolons and in sprouting tubers. StCDPKl genomic sequence contains eight exons and seven introns, the gene structure is similar to Arabidopsis, rice and wheat CDPKs belonging to subgroup IIa. There is one copy of the gene per genome and it is located in the distal portion of chromosome 12. Western blot and immunolocalization assays (using confocal and transmission electron microscopy) performed with a specific antibody against StCDPK1 indicate that this kinase is mainly located in the plasma membrane of swelling stolons and sprouting tubers. Sucrose (4-8\%) increased StCDPK1 protein content in non-induced stolons, however the
\end{abstract}

The StCDPK1 codifying and genomic sequences have the GenBank Database accession numbers AF115406, and DQ507862.1 respectively.

P. R. Gargantini · V. Giammaria · C. Grandellis .

R. M. Ulloa ( $\square)$

Instituto de Investigaciones en Ingeniería Genética y Biología

Molecular, CONICET and Facultad de Ciencias Exactas y

Naturales, Universidad de Buenos Aires, Vuelta de Obligado

2490, piso 2, 1428 Buenos Aires, Argentina

e-mail: rulloa@dna.uba.ar

S. E. Feingold

Laboratorio de Agro-Biotecnología, INTA-EEA Balcarce,

CC276, 7620 Balcarce, Argentina

S. Maldonado

Departamento de Biodiversidad y Biología Experimental, Lab.

17 Facultad de Ciencias Exactas y Naturales, Universidad de

Buenos Aires, C1428EGA Buenos Aires, Argentina

Present Address:

P. R. Gargantini

Departamento de Bioquímica, Instituto de Química,

Universidade de São Paulo, Sao Paulo, Brazil amount detected in swelling stolons was higher. Transgenic lines with reduced expression of StCDPK1 ( $\beta 7)$ did not differ from controls when cultured under multiplication conditions, but when grown under tuber inducing conditions some significant differences were observed: the $\beta 7$ line tuberized earlier than controls without the addition of CCC (GA inhibitor), developed more tubers than wild type plants in the presence of hormones that promote tuberization in potato (ABA and BAP) and was more insensitive to GA action (stolons were significantly shorter than those of control plants). StCDPK1 expression was induced by GA, $\mathrm{ABA}$ and BAP. Our results suggest that StCDPK1 plays a role in GA-signalling and that this kinase could be a converging point for the inhibitory and promoting signals that influence the onset of potato tuberization.

Keywords Calcium-dependent protein kinases . Solanum tuberosum - Tuberization · Gibberellins

\section{Introduction}

Plant cells are equipped with highly efficient mechanisms to perceive, transduce and respond to a wide variety of internal and external signals during their growth and development. Perception of signals via receptors results in generation of second messengers that control diverse cellular processes. Calcium $\left(\mathrm{Ca}^{2+}\right)$ is a crucial regulator in plants and nearly all environmental, hormonal and developmental stimuli use it as a signalling molecule.

There can be magnitudinal, spatial and temporal aspects of individual $\mathrm{Ca}^{2+}$ signals and these characteristics might be informative in ways that enable decoding of this ' $\mathrm{Ca}^{2+}$ signature' to elicit specific and appropriate responses (Evans et al. 2001). Although such $\mathrm{Ca}^{2+}$ signatures may 
partially explain the specificity of cellular responses triggered by a particular stimulus, the molecules that "sense" and "interpret" the $\mathrm{Ca}^{2+}$ signals provide additional specificity to the coupling of $\mathrm{Ca}^{2+}$ parameters to cellular responses. Plant protein kinases are a large and differentiated group of calcium sensors, among them, the $\mathrm{Ca}^{2+}$ dependent protein kinase (CDPK) family plays distinct roles in mediating $\mathrm{Ca}^{2+}$ signalling (Klimecka and Muszyńska 2007).

CDPKs are monomeric proteins, with an N-terminal variable domain, a kinase domain, an autoinhibitory domain, a regulatory domain (CaM-LD, calmodulin-like domain) and a C-terminal domain of variable length (Harmon 2003). CDPKs are unique owing to the presence of CaM-LDs that are able to couple the calcium sensor directly to its responder (kinase). CDPKs are encoded by multigene families, for example in Arabidopsis thaliana there are 34 genes for CDPKs (Cheng et al. 2002; Hrabak et al. 2003) and 31 in Oryza sativa (Ray et al. 2007). A genome-wide analysis of Arabidopsis CDPKs provides an over-view of the diversity of this large multigene family and shows that gene duplication and subsequent divergence generated CDPKs with distinct functions. CDPKs are found in various subcellular localizations which suggest that this family may be involved in multiple signalling pathways (Lu and Hrabak 2002). Enhanced CDPK activity/expression has been linked to different stress responses and numerous environmental stimuli (Klimecka and Muszyńska 2007).

Potato tuberization is an ideal model system to study gene expression during organ development. Tuberization is a highly coordinated morphophysiological process occurring on the underground stolons under the influence of both extrinsic and intrinsic factors (Sarkar 2008). Tubers are underground modified stems that serve as a storage organ and as a vegetative propagation system. During the early stages of tuber formation stolons alter their growth habit, displaying a cessation of elongation and the initiation of subapical radial growth. Increased cell division and expansion are followed rapidly by a massive deposition of starch and storage proteins as a result of the coordinated expression of genes involved in starch and protein biosynthesis (Prat et al. 1990; Visser et al. 1994). The transformation of stolons into tubers impacts greatly on the whole plant physiology because developing tubers subsequently become the largest sinks present.

Potato plants produce tubers as a result of the changing balance of endogenous growth regulators, which is brought about by the plant's ability to perceive changing environmental conditions (Cutter 1978; Rodríguez-Falcón et al. 2006). Sugars and phytohormones play an important role in tuber formation (reviewed in Jackson 1999 and in Sarkar 2008; Fernie and Willmitzer 2001). Several lines of evidence implicate gibberellins (GAs) in the inhibition of tuberization. All the environmental signals that regulate tuber development affect GAs concentration (Woolley and Wareing 1972; Krauss 1985; Menzel 1983, 1985). Gibberellins have been shown to inhibit tuberization using both in vivo and in vitro experiments (reviewed in Vreugdenhil and Sergeeva 1999). Antisense expression of a GA 20-oxidase gene (Carrera et al. 2000) or overexpression of a knottedlike homeobox gene (Rosin et al. 2003) that reduce the levels of bioactive gibberellins increased the rate of tuberization. Similarly, exogenous application of gibberellins decreased tuberization (Simko 1994; Xu et al. 1998) whereas application of the gibberellin biosynthesis inhibitor, paclobutrazol, increased tuberization (Simko 1994).

On the other hand, several studies using transgenic plants have provided evidence that increasing sugar concentrations can promote tuber formation (Müller-Röber et al. 1992; Sonnewald et al. 1997). In vitro experiments have shown that application of exogenous sucrose promotes tuberization (Garner and Blake 1989; Simko 1994; $\mathrm{Xu}$ et al. 1998; Raices et al. 2003c) and that the effects of sucrose on tuber formation are not due to alterations in the osmotic potential of the media (Perl et al. 1991). Sucrose has been proposed to affect tuberization, at least in part, via effects on the levels of bioactive gibberellins (Simko 1994; Xu et al. 1998).

Probably tuber development is the result of the relative balance of inducers (e.g. sucrose) and inhibitors (e.g. GAs) of tuberization (Jackson 1999). Sugar- and phytohormoneresponse pathways 'interact' in the regulation of many processes, however, little is known about the mechanisms by which they interact. Intracellular calcium is necessary for tuber development and calmodulin antagonists can inhibit this process (Balamani et al. 1986). An increase in cytosolic calcium concentration was reported in tobacco cells in response to sucrose (Furuichi and Muto 2005) and in GA-treated barley aleurone protoplasts (Gilroy and Jones 1992); thus it can be speculated that sucrose and GAs can induce a $\mathrm{Ca}^{2+}$ influx into the cytoplasm of potato cells.

In previous works we reported a temporal correlation between an increase in CDPK activity and the morphological changes associated with the onset of tuber development using in vitro cultured potato stolons (MacIntosh et al. 1996). We analyzed the expression and activity of potato CDPK isoforms that follow different expression profiles during tuberization (Raices et al. 2003a). Among them, StCDPK1 was transiently expressed in swelling stolons (Raices et al. 2001) and its expression was induced by high sucrose (Raices et al. 2003b). In this paper we analyze the genomic structure of StCDPK1 gene, its chromosome localization and we study how its expression is affected by the addition of different phytohormones. A genetically modified line, $\beta 7$, with low StCDPK1 expression produced more tubers when cultured under inducing 
conditions and responded anomaly to GAs suggesting that this kinase could be part of the signalling cascade triggered by GAs.

\section{Experimental procedures}

Plant material

Virus-free meristematic sprouts from Solanum tuberosum, L. var. Spunta wild type and StCDPK1-transgenic potato plants were micropropagated on a modified MS (Murashige and Skoog 1962) medium with $3 \%(\mathrm{w} / \mathrm{v})$ sucrose and $0.7 \%$ $(\mathrm{w} / \mathrm{v})$ agar under a $16 \mathrm{~h}$ light photoperiod at $23^{\circ} \mathrm{C}$ (multiplication conditions). Potato plants, Solanum tuberosum, L. cv. Spunta were cultivated in a greenhouse under a regime of $16 \mathrm{~h}$ light $\left(25^{\circ} \mathrm{C}\right)$ and $8 \mathrm{~h}$ dark $\left(20^{\circ} \mathrm{C}\right)$. Induced stolons with progressively swelling tips (2-8 $\mathrm{mm}$ diameter) were classified as stages 1 to 4 (S1-S4). Tubers were harvested and stored in the cold room.

\section{In vitro tuberization system}

Single node cuttings of 30 days-old wild type or StCDPK1transgenic potato plants were grown in tuberization medium: Murashige and Skoog salts supplemented with low nitrate concentration $\left(82.5 \mathrm{mg} \mathrm{l}^{-1} \mathrm{NO}_{3} \mathrm{NH}_{4}\right.$ and $95 \mathrm{mg} \mathrm{l}^{-1}$ $\mathrm{NO}_{3} \mathrm{~K}$ ), $8 \%(\mathrm{w} / \mathrm{v})$ sucrose, $0.7 \%(\mathrm{w} / \mathrm{v})$ agar, $\left.\mathrm{pH} 5.7\right)$ under complete darkness at $20^{\circ} \mathrm{C}$ during the indicated periods of time. Alternatively, 0.05 or $0.5 \mathrm{mg} \mathrm{m}^{-1}$ chlorocholine chloride (CCC); 0.05 or $0.5 \mu \mathrm{M}$ GA3 gibberellic acid (GA); $7.6 \mu \mathrm{M}$ absicic acid (ABA) or $5 \mathrm{mg} \mathrm{ml}^{-1}$ benzilaminopurine (BAP) were added to the culture media. In addition, the single node cuttings were grown in the presence of different sucrose concentrations $(2,4$ or $6 \% \mathrm{w} / \mathrm{v})$. To analyze the effect of a short GA-treatment, single-node cuttings grown during 13 days in tuberization conditions were transferred during 2 or $6 \mathrm{~h}$ to the same media with the addition of $0.5 \mu \mathrm{M}$ GA.

\section{StCDPK1 transgenic plants}

The N-terminal variable domain of StCDPK1 (GenBank Database, accession number AF115406) spanning from the ATG to subdomain I of the kinase catalytic domain ( $\sim 350$ bp) was amplified using primers Pa18 (5'GGATCC TCTGGGGTTGTTGTTTTC $3^{\prime}$ ) and Pa19 (5'TGGGTAGA GGTCAATATGGGGGGATCC $3^{\prime}$ ) and subcloned in pGEM T-easy (Promega). After digestion with BamH1, the restriction fragment was subcloned in sense orientation into the pGUT binary vector (pUC18-derived plasmid containing the numbers $3^{\prime}$ region of $\mathrm{pBI}$ 101.1) under the control of the specific tuber promoter of the Granule-Bound Starch
Synthase (GBSS). Agrobacterium tumefaciens (GV2260-6) mediated transformation of microtuber discs (50) was performed on MS medium supplemented with $5 \mu \mathrm{M}$ zeatin riboside and $5 \mu \mathrm{M}$ indoleacetic acid to induce the organogenesis. Discs were transferred to selection media (250 $\mathrm{mg} \mathrm{l}^{-1}$ cefotaxime and $50 \mu \mathrm{g} \mathrm{ml}^{-1}$ kanamycin) $48 \mathrm{~h}$ post-infection, and then to fresh media every 20 days. The 54 transformant plantlets were transferred to individual flasks and grown in MS media with kanamycin. Presence of the transgene was confirmed in Southern blot assays or by PCR using genomic DNA as template and the following pair of primers that amplify a $600 \mathrm{bp}$ fragment: $\mathrm{P}_{\mathrm{GBSS}}$ $\left(5^{\prime}\right.$ CTCACTCACACAGCTCAAC $\left.3^{\prime}\right)$, specific for the GBSS promoter, and Pa19. Plants regenerated from untransformed in vitro shoots were used as wild-type controls.

\section{Cloning of StCDPK1 gene}

A Solanum tuberosum var. Desireé genomic library (Clontech) was screened using a full length StCDPKI coding sequence as a probe. Three rounds were performed to get a positive clone designated 4.1.b. The phage was purified following the instructions of the Lambda Midi Kit (QIAGEN). Automated sequencing was performed at the DNA Sequencing facility (University of Chicago, USA). Assembly and analysis of DNA sequence data was done using software available at the NCBI's Advanced BLAST sequence similarity search, designed to support analysis of nucleotide and protein databases. Clone 4.1.b (2,300 bp) lacked the $3^{\prime}$ end of the gene and the kinase catalytic domain, therefore a PCR strategy was designed to obtain the full-length genomic sequence. Specific primers directed against the codifying sequence of StCDPK1 (Mar1, Pa8, Pa9, Pa10, Pa11, Pa3, R10-2), the intronic sequences of clone 4.1.b. (Pa6, Pa12, Pa13) or the $3^{\prime} \mathrm{UTR}$ region of the gene (St1UTR) were used to amplify PCR fragments using genomic DNA as template (primers are indicated in Fig. 1A). The amplified fragments were subcloned in pGEM-Teasy (Promega), sequenced (Macrogen Inc., Korea) and compiled. Intronic sequences were identified using software to determine splicing sites. The complete genomic sequence (5952 nt) was submitted to GenBank (Accession number DQ507862.1).

DNA isolation and southern blot hybridization

Genomic DNA was extracted from greenhouse potato plants according to Murray and Thompson (1980). DNA $(10 \mu \mathrm{g})$ was digested with restriction enzymes (EcoRI, BamH1 and HindIII) (New England Biolabs, Beverly, MA), separated on $0.7 \%$ agarose gels and blotted under denaturing conditions onto Hybond $\mathrm{N}+$ positively charged 


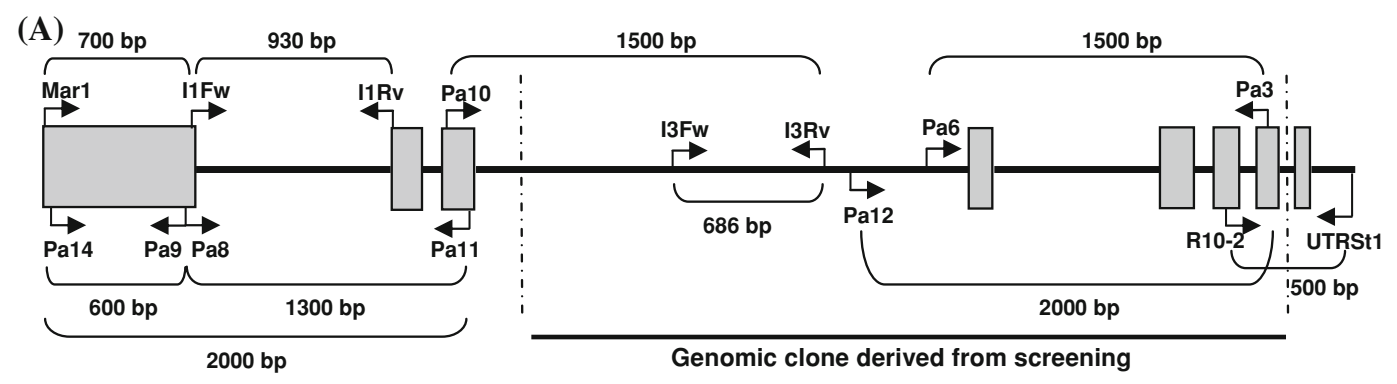

(B)

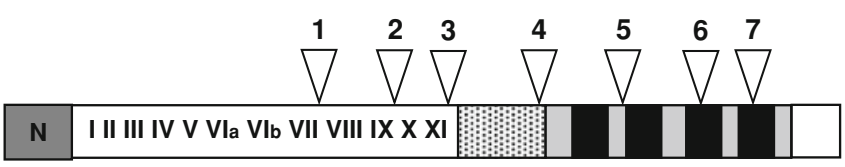

(C)

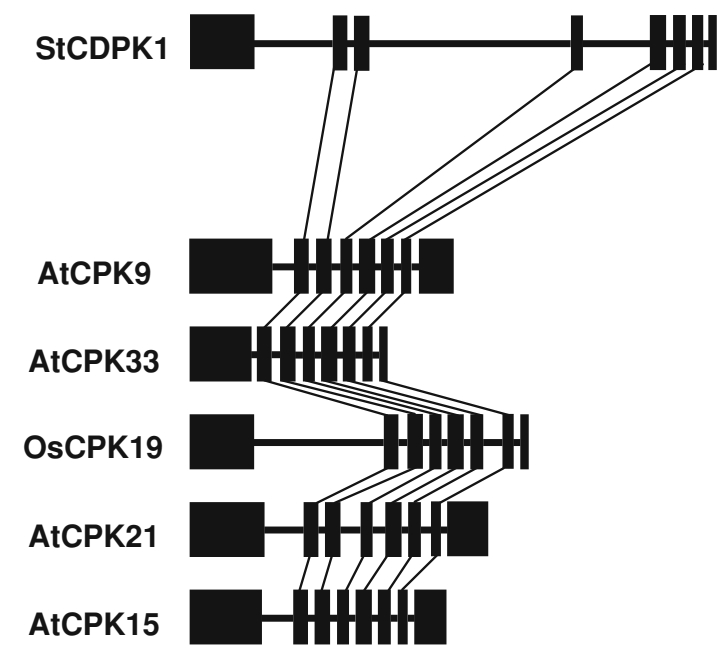

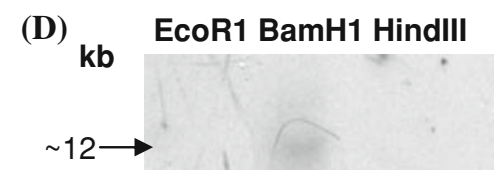

(D)
Fig. 1 Analysis of StCDPK1 gene. A Schematic representation of StCDPK1 gene cloning strategy. The genomic clone obtained by screening a genomic Clontech potato library is indicated. Primers used to amplify the different sequences using genomic DNA as template and the length of each amplicon is indicated. Exons are represented as grey boxes and introns as lines. B Genomic structure of $S C D P K 1$ gene. Intron locations (1-7) relative to the protein sequences are shown by triangles. The exact sizes of exons and introns can be found in Table 1. Dark grey box: N-terminal variable domain; white

nylon membranes (Amersham) according to the manufacturer's procedures. Membranes were hybridized overnight with a $\left[{ }^{32} \mathrm{P}\right]$-labelled intronic sequence (INT 1$)$ of the gene at $65^{\circ} \mathrm{C}$ in Church's buffer. Sequential stringent washes were performed $(2 \times \mathrm{SSC}, 1 \times \mathrm{SSC}$ and $0.1 \times \mathrm{SSC}$ with $0.1 \%$ SDS) during $30 \mathrm{~min}$ at $65^{\circ} \mathrm{C}$ and blots were exposed to X-OMAT Kodak films.

\section{Chromosome mapping}

The genetic location of StCDPK1 was determined using the single strand conformation polymorphism (SSCP) box: protein kinase domains; I-XI, subdomains of the protein kinase domain are indicated; dense dotted box: junction domains; light grey box: calmodulin-like domain containing $4 \mathrm{EF}$ hands (black). C Comparison of StCDPK1 gene structure with Arabidopsis and rice CDPKs belonging to subgroup IIa. The intronic sequences are drawn to scale. D Southern blot hybridization. Genomic DNA of potato plants $(12 \mu \mathrm{g})$ was digested with EcoR1, BamH1 and HindIII and separated on $0.7 \%$ agarose gels. After blotting, the DNA was probed with Amplicon I1 (930 bp). Size (in kb) of the bands is indicated

technique. Different pairs of primers, directed against exon-1 (Mar1, Pa9), intron-3 (I3Fw, I3Rv), or the 3'end of the gene (R10-2, $3^{\prime} \mathrm{UTR}$ ), were used to amplify PCR fragments from three parental genotypes (M200-30, B11B and H11-9) of two different mapping populations (BCB and BCT, Bonierbale et al. 1994). Amplified fragments were denatured in formamide and the ssDNAs were analyzed by 5\% MDE-PAGE (Cambrex, USA) and revealed with silver staining. The differences observed in the migration pattern reflect the nucleotide differences between the parental genotypes. Amplicon I3 showed two segregating bands in BCT population that were used for the 
mapping assays. Localization was performed by co-segregation of amplicon I3 with RFLP and SSR markers previously assigned to the different chromosomes (Bonierbale et al. 1994; Feingold et al. 2005) using the Mapmanager QTX software (www.mapmanager.org).

\section{Protein extraction}

Tuberization stages from Solanum tuberosum transgenic and control in vitro plants and swelling stolons from greenhouse plants (S1-S4) were harvested, ground in a mortar cooled with liquid nitrogen and extracted with $50 \mathrm{mM}$ Tris- $\mathrm{HCl} \mathrm{pH}$ 7.5; $2 \mathrm{mM} \beta$-mercaptoethanol; $1 \mathrm{mM}$ EDTA; $20 \%$ glycerol and protease inhibitors. The suspensions ( $1 \mathrm{ml}$ buffer/g of wet tissue) were centrifuged $10 \mathrm{~min}$ at $1,000 \mathrm{~g}$ and the pellet was discarded. The supernatant (crude extract) was centrifuged $1 \mathrm{~h}$ at $20,000 \mathrm{~g}$ and soluble and particulate fractions (Sn-20 k and P-20 k) were obtained. Pellets were washed with $0.5 \mathrm{ml}$ of extraction buffer and were then suspended in a volume equal to $10 \%$ of the volume of the soluble fraction. Alternatively, after the first centrifugation the supernatant was centrifuged at $10,000 \mathrm{~g}$ and subsequently at $100,000 \mathrm{~g}$. Both pellets (P-10 k and $\mathrm{P}-100 \mathrm{k}$ ) were suspended in extraction buffer.

\section{Isolation of plasma membrane fractions}

Plasma membranes (PM) from sprouting tubers were prepared by partition in an aqueous polymer two phase system according to Larsson et al. (1994). Potato tubers (59 g) were homogenized with a blender and a Polytron homogenizer (PT 3000; Kinematica AG, Lucerne, Switzerland) in $150 \mathrm{ml}$ of buffer A $(50 \mathrm{mM}$ Tris- $\mathrm{HCl} \mathrm{pH} 8,500 \mathrm{mM}$ sucrose, $10 \%$ glycerol, $20 \mathrm{mM}$ EDTA, $20 \mathrm{mM}$ EGTA, $0.6 \%$ w/v polyvinylpyrrolidone, $5 \mathrm{mM}$ DTT, $5 \mathrm{mM}$ $\beta$-glycerophosphate) with protease inhibitors (complete mini EDTA free Protease Inhibitor Cocktail Tablets, Roche Applied Science). The homogenates were filtered through three layers of cheesecloth and centrifuged at $10,000 \mathrm{~g}$ for $10 \mathrm{~min}$. The supernatant was further centrifuged at $50,000 \mathrm{~g}$ for $36 \mathrm{~min}$ and the resulting pellet (microsomal fraction) was suspended in $9 \mathrm{ml}$ of buffer B (330 mM sucrose, $2 \mathrm{mM}$ DTT in $5 \mathrm{mM}$ potassium phosphate $\mathrm{pH}$ 7.8). The microsomal fraction was separated through an aqueous two-phase partitioning system containing $6.6 \%$ dextran T500 (Amersham Pharmacia Biotech), 6.6\% polyethylene glycol P-3650 (Sigma), $5 \mathrm{mM} \mathrm{KCl,} 0.33 \mathrm{M}$ sucrose, and $5 \mathrm{mM}$ potassium phosphate buffer $(\mathrm{pH}$ 7.8). The resulting upper phases were designated the PM-rich fractions. These fractions were diluted with six volumes of buffer $\mathrm{C}$ (10 $\mathrm{mM}$ boric acid, $9 \mathrm{mM} \mathrm{KCl}, 300 \mathrm{mM}$ sucrose, $2 \mathrm{mM}$ DTT in $10 \mathrm{mM}$ Tris- $\mathrm{HCl} \mathrm{pH} 8.3$ with protease inhibitors) and centrifuged at $100,000 \mathrm{~g}$ for $36 \mathrm{~min}$. The pellets were suspended in buffer $\mathrm{C}$ and stored at $-80^{\circ} \mathrm{C}$. All procedures were carried out at $0-4^{\circ} \mathrm{C}$.

Analytical methods

Protein contents were determined with BioRad protein assay reagent with BSA as the standard.

The hydrolytic activity of vanadate-sensitive ATPase (PM-H ${ }^{+}$-ATPase) was used as a marker of PM. ATPase activity was determined in the PM-rich fractions and in microsomal (Mi) fractions of sprouting tubers at $37^{\circ} \mathrm{C}$ for $25 \mathrm{~min}$ as described (Larsson et al. 1994). The reaction mixture contained $5 \mu \mathrm{g}$ of protein (PM or $\mathrm{Mi}$ ), $50 \mathrm{mM}$ MES (pH 6.5), $3 \mathrm{mM}$ ATP, $2.5 \mathrm{mM} \mathrm{MgSO} 4,50 \mathrm{mM} \mathrm{KCl}$, $1 \mathrm{mM} \mathrm{NaN} 3,0.1 \mathrm{mM} \mathrm{Na}_{2} \mathrm{MoO}_{4}, 160 \mathrm{mM}$ sucrose and $0.02 \%$ Triton X-100. PM H+-ATPase activity was assayed in the presence or not of $0.6 \mathrm{mM} \mathrm{Na} \mathrm{Na}_{3}$ and was expressed as the difference between the activity measured in the absence and in the presence of $\mathrm{Na}_{3} \mathrm{VO}_{4}$. The $\mathrm{Pi}$ released during the reaction was assayed by a colorimetric method based on that of Fiske and Subbarow (1925).

CDPK activity was determined in soluble, microsomal and enriched plasma membrane fractions as described (MacIntosh et al. 1996). The reaction mixture contained $20 \mathrm{mM}$ Tris- $\mathrm{HCl} \mathrm{pH} 7.5,10 \mathrm{mM} \mathrm{MgCl}{ }_{2}, 50 \mu \mathrm{M}\left[\gamma_{-}{ }^{32} \mathrm{P}\right]$ ATP (specific activity $100 \mathrm{cpm} / \mathrm{pmol}$ ), $10 \mathrm{mM}$ 2-mercaptoethanol, $25 \mu \mathrm{M}$ Syntide-2, with the addition of $1 \mathrm{mM}$ EGTA or $5 \mu \mathrm{M} \mathrm{CaCl}_{2}$. Specific CDPK activity, expressed as $\mathrm{nmol}$ of ${ }^{32} \mathrm{P}$ incorporated per minute per $\mathrm{mg}$ protein, is the difference between the activities detected in the presence of calcium and EGTA.

\section{Anti-StCDPK1 polyclonal antibody}

The StCDPK1 N-terminal variable domain (634 bp) was amplified using primers PaR1-BamH1 (5'CGCGGATCCG AGCAAAAGTAAACCAGC3') and PaR2-XhoI (5'CCGC TCGAGCTCAGGCTTAAGATCACG3'), digested with Bam $\mathrm{H} 1$ and XhoI restriction enzymes (New England Biolabs) and subcloned into the pET22b+ vector (Novagen). The StCDPK1- $6 \times$ His recombinant protein was expressed in E. coli BL21pLysS strain and purified by affinity chromatography using a nickel column (Ni-NTA agarose, Qiagen). The purified recombinant protein $(0.8 \mathrm{mg} / \mathrm{dose})$ was used as antigen to produce antibodies in rabbit. The polyclonal serum was purified using a Sepharose CL4B-Protein A column. The antibodies were used in Western blot (1:400) and immunolocalization (1:100) assays.

Western blot assays

SDS-PAGE was carried out as described by MacIntosh et al. (1996). Pre-stained SDS-PAGE standards from 
Invitrogen or Fermentas Life Sciences were used as molecular weight markers. Western blot analysis of protein samples $(50-100 \mu \mathrm{g})$ from tuberization stages (S1-S4) or from sprouting tubers was performed using affinity purified polyclonal anti-StCDPK1 antibodies (1:400).

Blots were developed with ECL reagent from Amersham (according to the manufacturer's procedure). The signal was scanned and quantified with ImageQuant software.

Immunolocalization assays

Swelling stolons (S4) were fixed overnight at $4{ }^{\circ} \mathrm{C}$ with $4 \%$ paraformaldehyde in $0.05 \mathrm{M}$ phosphate buffer, $\mathrm{pH} 7$, washed three times with phosphate buffer (30 min each), dehydrated in a graded ethanol series with changes every 30 min and embedded in LR White resin (Polyscience, Inc. 17411) according to Harris (1994). Semithin longitudinal sections $(7 \mu \mathrm{m})$ or ultra-thin sections were obtained using an ultramicrotome (Reichert-Jung, Vienna, Austria) with a glass knife.

Semithin sections were hydrated with $0.05 \%$ v/v Tween 20 in $1 \times$ TBS (TBS-Tw) during $10 \mathrm{~min}$, blocked with $5 \%$ normal donkey serum in TBS-Tw during $2 \mathrm{~h}$ and rinsed three times with TBS-Tw (5 min each). After incubation with affinity purified polyclonal anti-StCDPK1 antibody (1:100 in TBS-Tw) during $2 \mathrm{~h}$, sections were incubated in the dark for $1 \mathrm{~h}$ with a secondary anti-rabbit antibody conjugated to Cy3 (1:100 in TBS-Tw) (Jackson Lab.), rinsed three times with TBS-Tw, once with water and were left to dry. Mowiol 4-88 and cover slips were added and sections were kept overnight in the dark at room temperature. Control sections were treated as above but rabbit preimmune serum was used as primary antibody. Fluorescence was observed with a Leica DM LB epifluorescent microscope equipped with a mercury lamp $(50 \mathrm{~W}$, Wetzlar, Germany) and a filter system suitable for Cy3. Images were obtained with a CCD camera.

Ultrathin sections were mounted on Formvar-coated nickel grids (Polyscience, Inc. 7550N) for immunolabeling at the TEM level. Sections were first hydrated on a drop of Milli-Q-grade water for $3 \mathrm{~min}$, washed with rinsing buffer twice for $3 \mathrm{~min}$, blocked for $90 \mathrm{~min}$ with $1 \%$ gelatin in PBS at room temperature, washed with rinsing buffer twice ( 3 min each) and incubated overnight at $4^{\circ} \mathrm{C}$ with the purified rabbit anti-StCDPK1 primary antibody at a 1:100 dilution in the rinsing buffer. Next, sections were washed with rinsing buffer (five changes, $5 \mathrm{~min}$ each), incubated for $1 \mathrm{~h}$ on a drop of colloidal gold $(10 \mathrm{~nm})$-conjugated goat antiserum to rabbit immunoglobulins diluted 1:100 in rinsing buffer at room temperature and washed again with rinsing buffer (five changes, $5 \mathrm{~min}$ each). After a 10-min fixation with $1 \%$ glutaraldehyde in $0.1 \mathrm{M} \mathrm{PBS,} \mathrm{pH} 7.2$, sections were thoroughly washed with Milli-Q-grade water. Finally, grids carrying sections were counter-stained with uranyl acetate, and examined under a ZEISS EM 109 turbo (Wiesbaden, Germany) transmission electron microscope operating at an accelerating voltage of $90 \mathrm{kV}$. Control sections were treated as above, excluding the purified rabbit StCDPK1 immune serum.

RNA extraction

Total RNA was extracted from different tuberization stages or from dormant and sprouting tubes with the Total RNA Isolation, TRIzol, Reagent (Gibco-BRL) following the manufacturers' instructions.

\section{Semiquantitative RT-PCR analysis}

Total RNAs $(10 \mu \mathrm{g})$ were pre-treated with DNAse (RQ1 RNAse-free DNAse, Promega,) and reverse transcribed with M-MLV-Reverse Trancriptase (Promega) using an oligo-dT primer. Control reactions to check equal amounts of cDNA template were performed using primers Ubil (5'ATGCAGATCTTTGTGAAGAC3') and Ubi2 (5'ACCA CCACGGAGACGGAG3') to amplify a $250 \mathrm{bp}$ ubiquitin fragment (20 cycles, annealing temperature $55^{\circ} \mathrm{C}$ ).

Semiquantitative RT-PCR was carried out according to Raices et al. (2003a) using specific primers to exclusively amplify $S t C D P K 1$ and $S t C D P K 3$. A common $5^{\prime}$ primer, $5^{\prime} S t$ (5'GGAAGCTGCTGATGTGGATGG3') present in both StCDPK sequences was combined with different $3^{\prime}$ primers derived from the $3^{\prime} \mathrm{UTR}$ region of each kinase. PCRs (30 cycles) were performed with Platinum Taq polymerase (Invitrogen). Annealing temperature was $64^{\circ} \mathrm{C}$ for StCDPK 1 and $61^{\circ} \mathrm{C}$ for StCDPK3. Control reactions with plasmids (5 ng) yield amplified fragments corresponding to StCDPK1 and StCDPK3 of 419 and 498 bp respectively. In addition, the expression of $G A$ 2-oxidase (GA-2ox) and $G A$ 20-oxidase (GA-20ox) was determined using specific oligonucleotides. The clones containing GA-2ox and GA-20ox coding sequences were a kind gift of Dr. Salomé Prat.

RT-PCR products were separated on $1 \%$ agarose gels, blotted onto Hybond $\mathrm{N}+$ positively charged nylon membranes (Amersham) and hybridised to specific radiolabelled DNA probes. Probes against StCDPK1, StCDPK3, $G A-2 o x$ and GA-20ox were generated by random priming using the RadPrime DNA labelling system kit (Invitrogen) from PCR products amplified from cDNA clones. Hybridization conditions were the same as in Raices et al. (2003a). Signal was scanned with a phosphorimager Storm 830 (Amersham Pharmacia Biotech) and quantified with ImageQuant software. 


\section{Results}

Cloning and characterization of StCDPK1 gene

A partial genomic clone of StCDPK1 ( 2,300 bp) was obtained by screening a potato genomic library (Clontech). This clone contained four intronic regions and four exons that encoded the hinge region and the carboxyterminal regulatory domain of the kinase except for the last $75 \mathrm{bp}$ (Fig. 1A). In order to obtain the complete sequence of the gene, different PCRs were performed using genomic DNA as template with primers directed against the $5^{\prime}$ end of the kinase, the catalytic domain, the $3^{\prime} \mathrm{UTR}$ or the intronic regions (primers are indicated in Fig. 1A). Using this strategy we obtained the complete sequence of the gene (5,952 bp long from the ATG to the stop codon; GenBank Accession Number DQ507862, plus the $3^{\prime}$ UTR of the gene that spans a 357 bp sequence to the polyadenylation signal, GenBank Accession Number AF115406). In order to reveal the gene structure of $S t C D P K 1$, mRNA splicing sites were mapped by comparing the coding and the genomic sequences.

StCDPK1 gene is organized in eight exons and seven intronic regions (Table 1, Fig. 1B). The intron-exon

Table 1 Characteristics of StCDPK1 gene

\begin{tabular}{llllcl}
\hline Exons & $\begin{array}{l}\text { Length } \\
(\mathrm{bp})\end{array}$ & $\begin{array}{l}\text { GC content } \\
(\%)\end{array}$ & Introns & $\begin{array}{l}\text { Length } \\
(\mathrm{bp})\end{array}$ & $\begin{array}{l}\text { GC content } \\
(\%)\end{array}$ \\
\hline 1 & 715 & 39 & 1 & 918 & 36 \\
2 & 144 & 44 & 2 & 97 & 33 \\
3 & 153 & 41 & 3 & 2301 & 35 \\
4 & 116 & 41 & 4 & 779 & 35 \\
5 & 168 & 43 & 5 & 97 & 37 \\
6 & 128 & 39 & 6 & 82 & 35 \\
7 & 100 & 41 & 7 & 79 & 32 \\
8 & 75 & 39 & & & \\
\hline
\end{tabular}

junctions obeyed the GT/AG rule (Shapiro and Senapathy 1987). The predicted splicing sites of StCDPK1 correspond to those reported for CDPKs from subgroup II-a, that includes 10 Arabidopsis isoforms (AtCPK9, 15, 19, 21, 22, 23, 27, 29, 31 and 33; Cheng et al. 2002), two rice isoforms (OsCPK12 and 19; Asano et al. 2005) and two wheat isoforms (TaCPK5 and 18; Li et al. 2008). The length of exons 2-7 is conserved in all these isoforms (Table 2, and schematic representation in Fig. 1C). Exon 1 contains the N-terminal variable domain and subdomains I-VII of the catalytic domain, exon 2 contains subdomains VIII and IX while exon 3 completes the kinase catalytic domain. Exon 4 encodes the hinge region, and the regulatory domain is encoded by exons 5-8 (Fig. 1B, EF hands are represented in black). StCDPK1 can be considered a GC-poor gene; its overall GC content is $37 \%$, being higher in exons (39$44 \%)$ than in introns $(32-37 \%)$ (Table 1). The intronic regions present in $S t C D P K 1$ are much longer than those present in the Arabidopsis CDPK genes (schematic representation in Fig. 1C). While these range from 21 to $50 \%$ of the gene sequence and represent in average 34\% (http:// mips.gsf.de/cgi-bin/) StCDPK1 introns represent $74 \%$ of the total gene sequence.

PCR were performed with primers I1Fw-I1Rv, using genomic DNA from $S$. tuberosum potato plants (4n) or from two diploid parental lines, HB-171 and DB226, as template. The purified fragments (amplicon I1, derived from intron 1; $930 \mathrm{bp}$ ) were digested with BamH1, HindIII or EcoR1 to confirm that amplicon I1 does not present these restriction sites (data not shown). Genomic DNA digested with BamH1, HindIII or EcoR1 was probed with amplicon I1. Southern blot hybridization patterns were compatible with the presence of one copy of the StCDPK1 gene per genome (Fig. 1D). In experiments performed with the full-length codifying sequence as probe, several bands were revealed (data not shown; Raices et al. 2001) in accordance with the presence of several CDPK isoforms in the potato genome.
Table 2 Comparison of StCDPK1 with Arabidopsis and rice $C D P K$ genes belonging to subgroup IIa

\begin{tabular}{lllllll}
\hline Genes & Length $(\mathrm{bp})$ & \multicolumn{1}{c}{} \\
\cline { 2 - 6 } & StCDPK1 & AtCPK9 & AtCPK33 & OsCPK19 & AtCPK21 & AtCPK15 \\
\hline ATG-Stop & $\mathbf{5 9 5 0}$ & $\mathbf{2 9 0 7}$ & $\mathbf{2 1 5 8}$ & $\mathbf{3 7 5 0}$ & $\mathbf{3 2 8 8}$ & $\mathbf{2 8 2 1}$ \\
Exon 1 & 715 & 923 & 682 & 718 & 831 & 809 \\
Exon 2 & 144 & 143 & 143 & 144 & 143 & 143 \\
Exon 3 & 153 & 152 & 152 & 153 & 152 & 152 \\
Exon 4 & 116 & 115 & 115 & 113 & 112 & 112 \\
Exon 5 & 168 & 167 & 167 & 168 & 167 & 167 \\
Exon 6 & 128 & 127 & 127 & 127 & 127 & 127 \\
Exon 7 & 100 & 99 & 99 & 100 & 99 & 99 \\
Exon 8 & 73 & 377 & 74 & 78 & 445 & 343 \\
\hline
\end{tabular}


StCDPK1 mapping experiments were performed with amplicon I3 using the single strand conformation polymorphism (SSCP) technique. The data obtained from two linkage maps suggest that $S t C D P K 1$ gene is located in the distal portion of chromosome 12. StCDPK1 was localized at $13.2 \mathrm{cM}$ from StI079 marker (LOD score: 4.2 ) in the M200-30 map and at 16.7 cM of this same marker in H11-9 map (LOD score: 3.4). St1079 is an unpublished microsatellite that is linked to STM2028 in both maps (at $10.8 \mathrm{cM}$ in M200-30 and totally linked in H11-9). The fact that the same position was obtained using both maps (two independent events) supports this result; however to determine the exact location, mapping should be performed in a higher density map.

\section{Immunologic analysis of StCDPK1}

Our previous results indicate that $S t C D P K 1$ is expressed in induced stolons and that the CDPK activity detected in tuberizing stolons was mainly associated to the particulate fraction. However Western blot assays performed with an antibody directed against the CLD of soybean $\alpha \mathrm{CDPK}$ (Bachmann et al. 1996) suggested that CDPK protein was more abundant in the soluble fraction of tuberizing stolons (Raices et al. 2003a). A specific anti-StCDPK1 antibody directed against the $\mathrm{N}$-terminal variable domain and part of the catalytic domain (including subdomain V) of StCDPK1 was produced. StCDPK1 mRNA (1,596 nt) encodes a predicted protein of $59 \mathrm{kDa}$ (Raices et al. 2001) with an apparent molecular weight of $60 \mathrm{kDa}$ when revealed with the anti-StCDPK1 antibody (Fig. 2).

Proteins extracts from different tuberization stages (S1S4) were centrifuged at $20,000 \mathrm{~g}$ and Western blot assays were performed using the supernatants $(100 \mu \mathrm{g})$ or the particulate fractions $(50 \mu \mathrm{g})$ (Fig. 2A). The anti-StCDPK1 antibody (1:400) detected a faint band in soluble extracts of tuberizing stolons (S1-S4) and a stronger and slightly faster migrating band in S3 and S4. This second band migrated as one of the two polypeptides $(\approx 60$ and $57 \mathrm{kDa})$ detected in the particulate fractions. Furthermore, the amount of the $\approx 60 \mathrm{kDa}$ band increased in particulate extracts of progressively tuberizing stolons (Fig. 2A, right panel) in accordance with the expression data (Raices et al. 2001). The lower band detected could correspond to another CDPK isoform. Though less protein was loaded, a stronger signal was detected in the particulate extracts suggesting that the higher CDPK specific activity determined in these fractions (Raices et al. 2003a, b, c) is due to the presence of more StCDPK1 protein.

Protein extracts from S4 tuberizing stolons were subjected to differential centrifugation. The particulate $(10 \mathrm{k}$ and $100 \mathrm{k})$ and soluble $(100 \mathrm{k})$ extracts were analyzed by

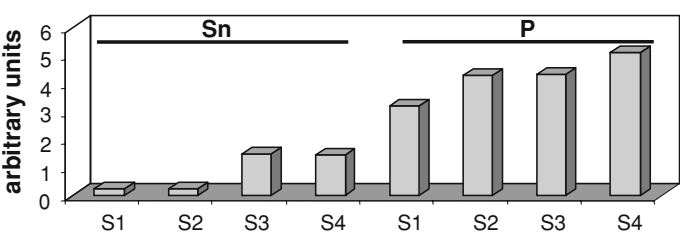

(C)
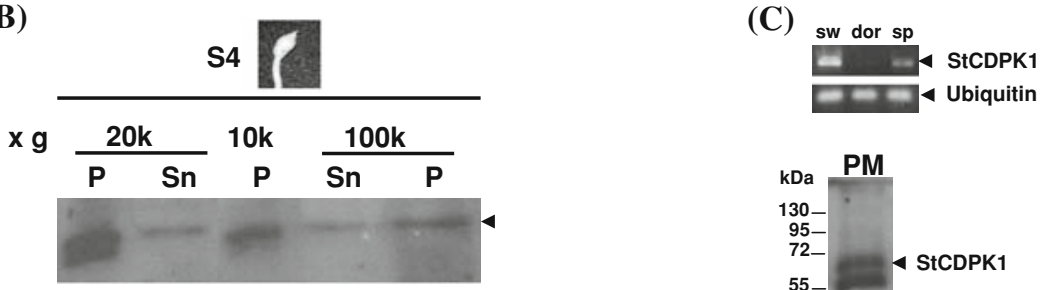

Fig. 2 Western blot analysis of StCDPK1 in swelling stolons and sprouting tubers. Protein extracts were subjected to electrophoresis and blotted. Membranes were incubated with a polyclonal antibody (1:400) against the N-terminal domain of StCDPK1 (A-C). The arrows indicate the $60 \mathrm{kDa}$ StCDPK1 band. A Soluble (S; $100 \mu \mathrm{g})$ or particulate fractions $(\mathrm{P} ; 50 \mu \mathrm{g})$ from different tuberization stages (S1S4) centrifuged at $20,000 \mathrm{~g}$ were analyzed by Western blot (left panel). Molecular weight markers are indicated. Signal was scanned and quantified (right panel). B Protein extracts $(50 \mu \mathrm{g})$ from S4 tuberizing stolons were either centrifuged at 20,000 $\mathrm{g}(20 \mathrm{k})$; or first at

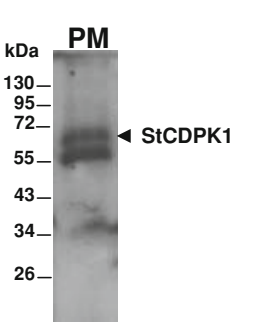

$10,000 \mathrm{~g}(10 \mathrm{k})$ and then at $100,000 \mathrm{~g}(100 \mathrm{k})$. Soluble (S) and StCDPK1 was performed in swelling stolons (sw) and in dormant (dor) or sprouting (sp) tubers from greenhouse plants. Equal amounts of total RNA were used and normalized using primers that amplify a constitutively expressed Ubiquitin gene. PCR to exclusively amplify StCDPK1 were performed using primers $5^{\prime} S t$ and $3^{\prime} S t 1$ (upper panel). The plasma membrane-rich $(\mathrm{PM})$ fraction $(30 \mu \mathrm{g})$ from sprouting tubers was analyzed. Molecular weight markers are indicated (lower panel) particulate $(\mathrm{P})$ fractions were analyzed. C RT-PCR analysis of 
Western blot (Fig. 2B). Two bands are observed in the $10 \mathrm{k}$ pellet while only the higher one is present in the microsomal fraction (P100 k); the same band is present in the cytosolic fraction $(\mathrm{Sn} 100 \mathrm{k})$ but as before, the signal is fainter.

StCDPK1 is also expressed in sprouting tubers but not in dormant ones (Fig. 2C, upper panel). Plasma membrane fractions (PM) from sprouting tubers were purified according to the two-phase partitioning method. Vanadatesensitive ATPase activity was used as marker of the plasma membrane $\left(33 \mu\right.$ moles $\left.\mathrm{Pi} \mathrm{h}^{-1} \mathrm{mg}^{-1}\right)$. CDPK activity was higher in the PM-rich fraction (12.1 nmoles ${ }^{32} \mathrm{P}$ incorporated. $\left.\mathrm{min}^{-1} \mathrm{mg}^{-1}\right)$ than in the soluble fraction $(2.8$ nmoles ${ }^{32} \mathrm{P}$ incorporated $\mathrm{min}^{-1} \mathrm{mg}^{-1}$ ) of sprouting tubers. The Western blot assay (Fig. 2C, lower panel) revealed two bands (60 and $57 \mathrm{kDa}$ ) in the PM-rich fraction from sprouting tuber while as before a very faint band was detected in the soluble fraction (data not shown). These data indicate that StCDPK1 protein and CDPK activity are associated to the plasma membrane.

In addition, longitudinal sections of S4 were incubated with anti-StCDPK1 or preimmune serum. As shown in Fig. 3A, the signal is observed surrounding nuclei and in the periphery of the cells of both periderm and neighbouring parenchyma tissues. Ultra-thin sections of swelling stolons (S2 and S4) were incubated with anti-StCDPK1 and incubated on a drop of colloidal gold $(10 \mathrm{~nm})$-conjugated goat antiserum to rabbit immunoglobulins, counter-stained with uranyl acetate, and examined under a transmission electron microscope (Fig. 3B-D). StCDPK1 was mainly located on the parietal cytoplasm and in the site corresponding to the plasma membrane. The protein was more abundant in S4 (Fig. 3D). Western blot data (Fig. 2B, C) are consistent with the association of StCDPK1 to cell membranes so we could suggest that in vivo StCDPK1 protein is mainly associated to plasma membrane.
Fig. 3 Immunolocalization analysis of StCPK1. A Longitudinal sections $(7 \mu \mathrm{m})$ of S4 tuberizing stolons were incubated with anti-StCDPK1 antibody (1:100). An anti-rabbit antibody conjugated to $\mathrm{Cy} 3$ (1:100) was used as secondary antibody. Sections were observed by LM. Protein was mainly located in living cells of the peridermis. The bar indicates $50 \mu \mathrm{m}$. B Ultrathin sections of S2 (B, C) and S4 (D) tuberizing stolons were incubated with the StCDPK1 primary antibody at a $1: 100$ dilution and then on a drop of colloidal gold-conjugated goat antiserum to rabbit immunoglobulins diluted 1:150. Sections were observed by TEM. Protein was mainly located in living cells of the peridermis, on the plasma membrane and in peripheral cytosol. Bars: $300 \mathrm{~nm}(\mathbf{B}, \mathbf{C})$, $500 \mathrm{~nm}$ (D). $c w$ Cell wall; $m l$ middle lamellae; $r$, ribosomes; $v$, vacuole. Arrows indicate gold particle labeling
(A)

S4
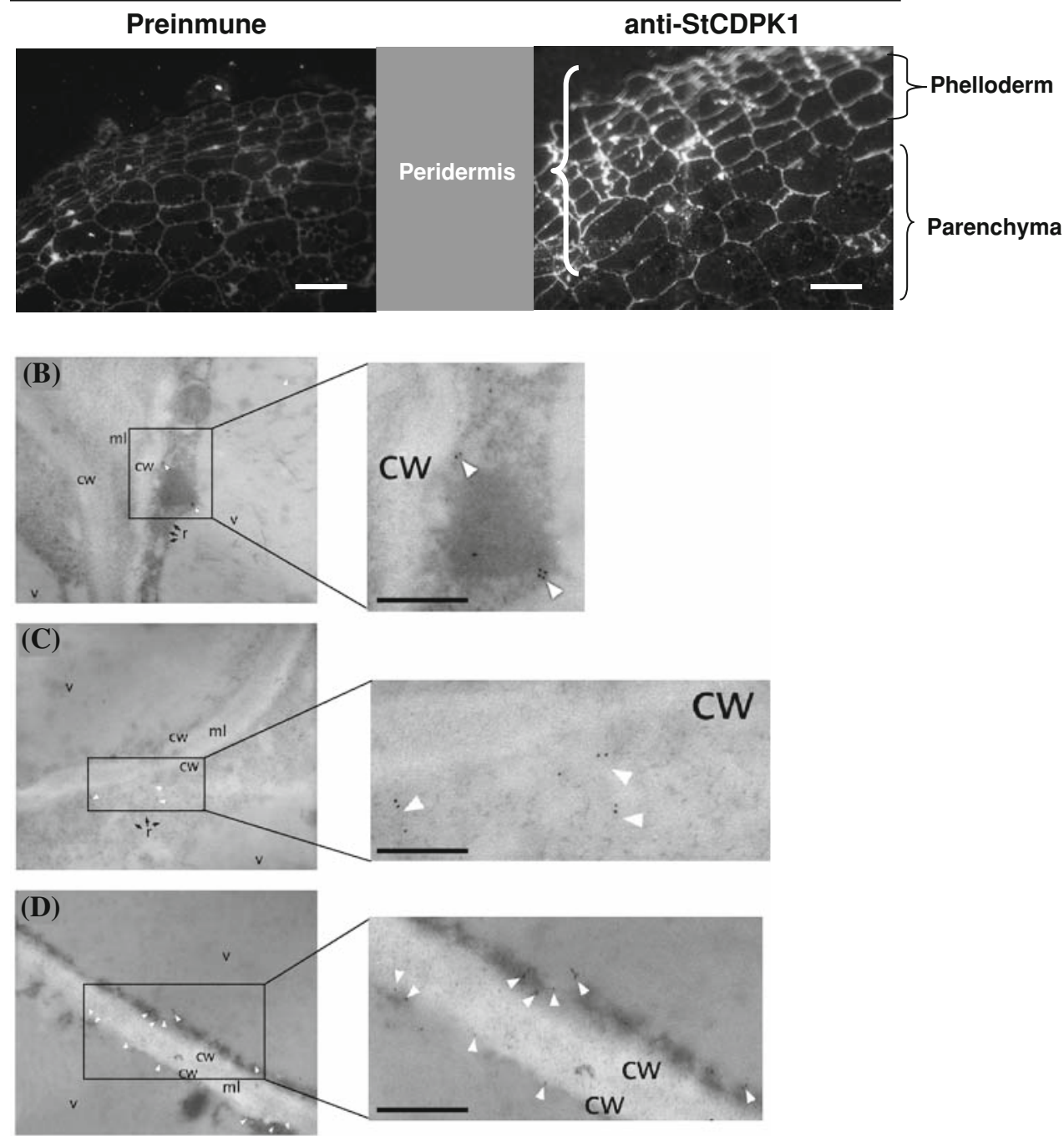
StCDPK1 expression was up-regulated in potato plants transferred during $16 \mathrm{~h}$ to liquid MS medium with $8 \%$ sucrose under light conditions (Raices et al. 2003b). Single node cuttings were grown during 8 days in MS with increasing amount of sucrose (2-8\%) under complete darkness. At the moment of harvest, non-induced stolons (NIS, where no swelling was observed) were collected from all conditions; however, in the $8 \%$ sucrose treatment some stolons were already induced to tuberize (IS). Total protein extracts were obtained from each condition, Western blot assays were performed and the bands were quantified (Fig. 4, upper and lower panels). An increase in StCDPK1 protein (1.5- to 2.5 -fold) was observed in noninduced stolons treated with 4,6 or $8 \%$ sucrose suggesting that sucrose regulates StCDPK1 expression even though there are no morphologic effects. However, when swelling of the stolon is evident (IS 8\% Sucrose), the amount of StCDPK1 protein detected was 5-fold higher than in controls $(2 \%$ sucrose) indicating that the kinase is developmentally regulated.

\section{StCDPK1 transgenic plants}

Our results suggest that StCDPK1 could be a component of the signalling cascades triggered during stolon to tuber transition. Thus we tried to obtain transgenic plants in

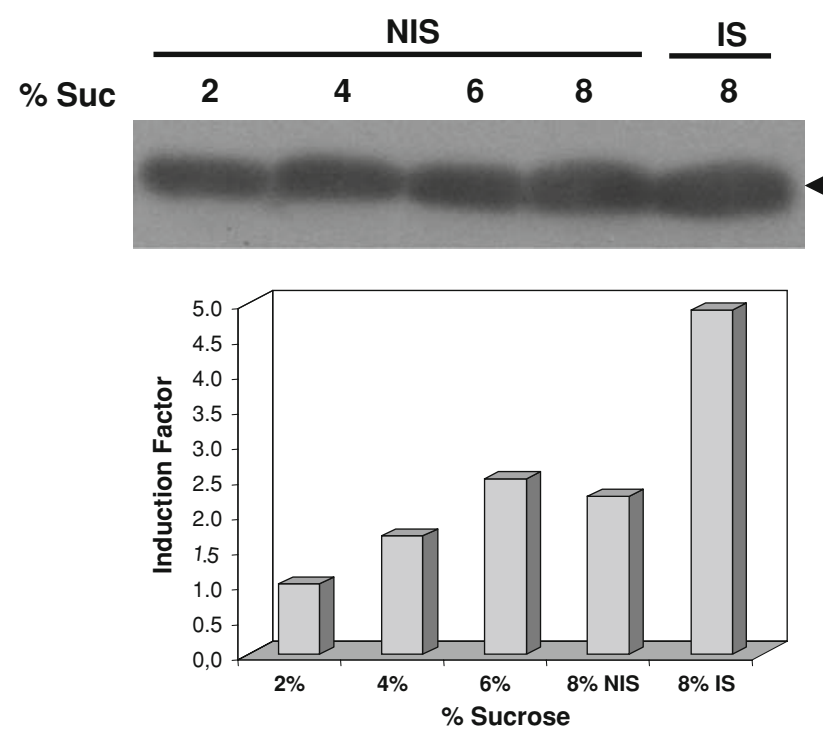

Fig. 4 Sucrose increases StCDPK1 protein content. Single node cuttings were grown during 8 days in MS with increasing amount of sucrose (4-8\%) under complete darkness. Control plants were grown in $2 \%$ sucrose. At the moment of harvest, non-induced stolons (NIS) or induced stolons (IS) were collected and total protein extracts were obtained, subjected to electrophoresis and blotted. Western blot assays were performed with $50 \mu \mathrm{g}$ of protein extracts (upper panel). Membranes were incubated with a polyclonal antibody (1:400) against the N-terminal domain of StCDPK1. The arrows indicate the $60 \mathrm{kDa}$ StCDPK1 band. Bands were quantified (lower panel) which StCDPK1 expression was modified and analyze them in conditions that promote or inhibit tuber formation. To this end, the variable $5^{\prime}$ end of the gene $(350 \mathrm{bp})$ was subcloned in sense orientation into the pGUT binary vector (Fig. 5A, upper panel). Agrobacterium mediated transformation of tuber discs was performed and 50 transformed shoots were selected on Kanamycin MS media. The presence of the transgene was confirmed by PCR using primers directed against the GBSS promoter and the Pa19 specific primer that amplify a $600 \mathrm{bp}$ fragment (Fig. 5A, lower panel) and by Southern blot (data not shown). Nodal stem cuttings from the different transgenic lines were cultured in vitro under tuber inducing conditions during 20 days; tuberizing stolons were harvested and total RNA was extracted. StCDPK1,StCDPK3 and ubiquitin expression was analyzed by semiquantitative RT-PCR (Fig. 5B, left panel). StCDPK1 expression was normalized relative to ubiquitin expression. StCDPK1 transcript levels varied in the different $\beta$ lines analysed but the lowest expression was observed in $\beta 7$ line (approximately one tenth of the expression observed in wild type plants (Fig. 5B, right panel) and this decrease in StCDPK1 transcript levels was correlated with a decrease in StCDPK1 protein content (Fig. 5C).

Control and $\beta 7$ plants were grown in multiplication and tuber inducing conditions. While no difference was observed in the phenotypic characteristics (root and stem length, number of internodes and chlorophyll content) of the in vitro plants grown in multiplication conditions (Fig. 6), the $\beta 7$ line displayed a different behaviour when grown under tuber inducing conditions (8\% sucrose, complete darkness, $20^{\circ} \mathrm{C}$ ). Control and $\beta 7$ single node cuttings were grown at the times indicated in the presence of $8 \%$ sucrose, $8 \%$ sucrose with CCC, inhibitor of gibberellin synthesis $\left(0.05\right.$ or $\left.0.5 \mathrm{mg} \mathrm{ml}^{-1}\right)$, or $8 \%$ sucrose with GA3 $(0.05$ or $0.5 \mu \mathrm{M})$. At the moment of harvest, stolons were separated into non-induced or induced to tuberize and tuber weight was assayed. CCC promoted tuberization both in wild type and $\beta 7$ plants at the times analysed (Table 3, Fig. 7A), however, the average weight of the $\beta 7$ microtubers was moderately higher than that of wild type ones (13 or $29 \%$ according to the CCC concentration used; Fig. 7A). On the contrary, no visible signs of tuber development were observed when control or $\beta 7$ plants were grown in the presence of GA3 and longitudinal stolon growth was increased (Table 3, Fig. 7B). This is consistent with the inhibitory effect of GAs on tuber formation and with its promoting effect on stolon elongation. However, the length of the non-induced stolons was significantly shorter in the $\beta 7$ line with both GA3 concentrations (Fig. 7B right panel), and this effect was even more evident when stem cuttings were exposed to $0.5 \mu \mathrm{M}$ GA3 for longer periods (Fig. 7B left panel). 


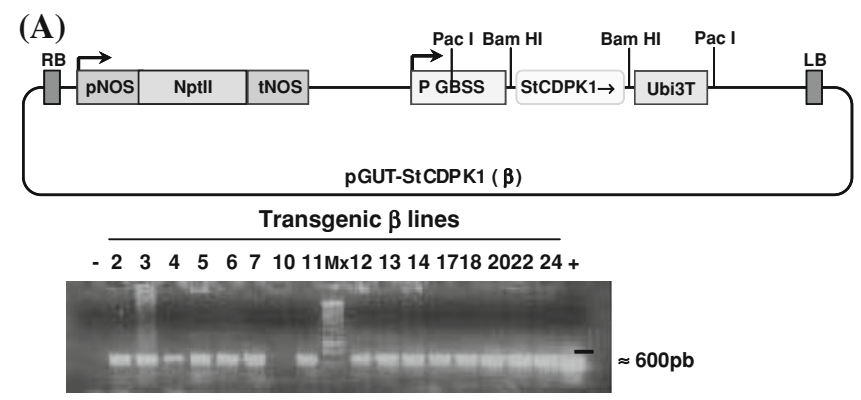

(B) Transgenic $\beta$ lines

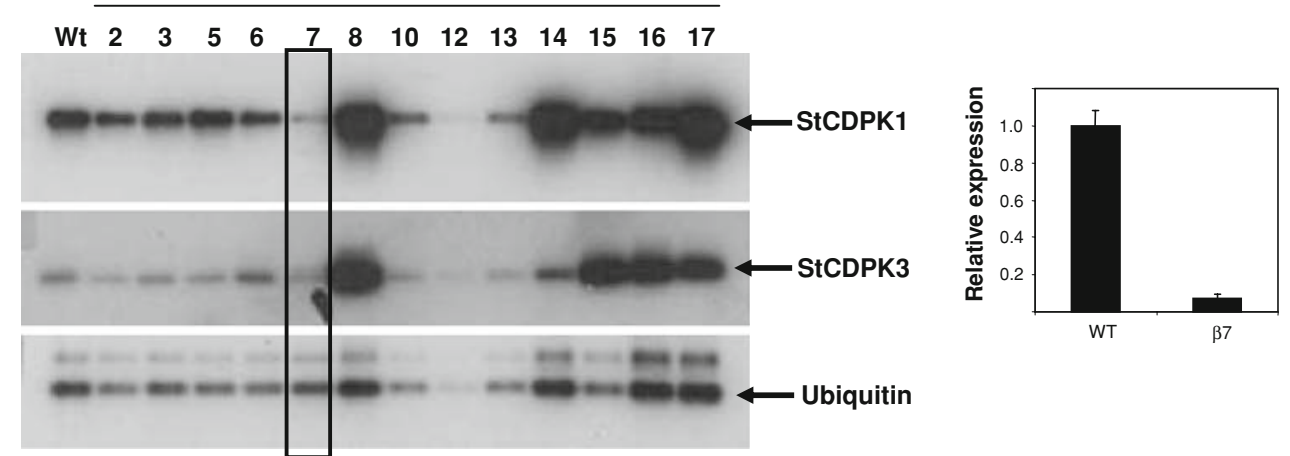

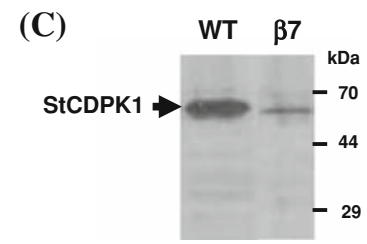

Fig. 5 Production of transgenic $\beta$ plants. A Schematic representation of the pGUT vector containing the N-terminal region (350 bp) of StCDPK1 (upper panel). The presence of the transgene in the transformed lines was confirmed by PCR using primers directed against the GBSS promoter and the Pa19 primer that amplify a $600 \mathrm{bp}$ fragment (lower panel). B StCDPK1 relative expression in wild type (WT) and transgenic $\beta$ plants. RT-PCR analysis of StCDPK1, StCDPK3 and Ubiquitin was carried out with specific primers. RT-

When grown in the presence of $8 \%$ sucrose, the $\beta 7$ line displayed a more pronounced tuberization response $(84 \%$ of the $\beta 7$ plants tuberized compared to $54 \%$ of the wild type plants, Table 3). A similar experiment was performed in the presence of $6 \%$ sucrose during 10 days. In these conditions, wild type plants yielded no tubers, however $20 \%$ of the $\beta 7$ stolons were induced to tuberize. High sucrose concentrations (6 or $8 \%$ ) affects the length of potato stolons, these were significantly $(P<0.01)$ shorter than those grown in $2 \%$ sucrose (Table 4 ). This effect was more noticeable in non-induced $\beta 7$ stolons.

The effect of ABA and BAP was also studied; single node cuttings from wild type and $\beta 7$ plants were cultured during 10 days under tuberization conditions in the presence of $7.6 \mu \mathrm{M}$ ABA or $5 \mathrm{mg} \mathrm{ml}^{-1}$ BAP (Fig. 8). Both
PCR products were separated on $1 \%$ agarose gels, blotted and hybridised to specific radio-labelled DNA probes (left panel). The value of $\beta 7$ was normalized to the expression of WT plant (=1) (right panel). C Western blot analysis of total protein extracts $(75 \mu \mathrm{g})$ from wild type (WT) or $\beta 7$ induced stolons with a specific antibody against StCDPK1 (1:400). Molecular weight markers are indicated (left panel). Bands were quantified, StCDPK1 protein content for $\beta 7$ is normalized to that of the WT plant (=1) (right panel)

hormones positively regulated tuber development being ABA more effective than BAP. In both conditions, $\beta 7$ plants developed more tubers than wild type plants.

Expression analysis of StCDPK1

in response to phytohormones

RNA was obtained from the different treatments $(8 \%$ sucrose and $8 \%$ sucrose with the addition of ABA, BAP or GA) and StCDPK1 expression was assayed. Data are shown relative to expression of ubiquitin and in all cases controls ( $8 \%$ sucrose) are set as 1 (Fig. 9A). The expression of StCDPK1 was induced with the addition of the phytohormones (Fig. 9A, left panel). ABA treatment produced 

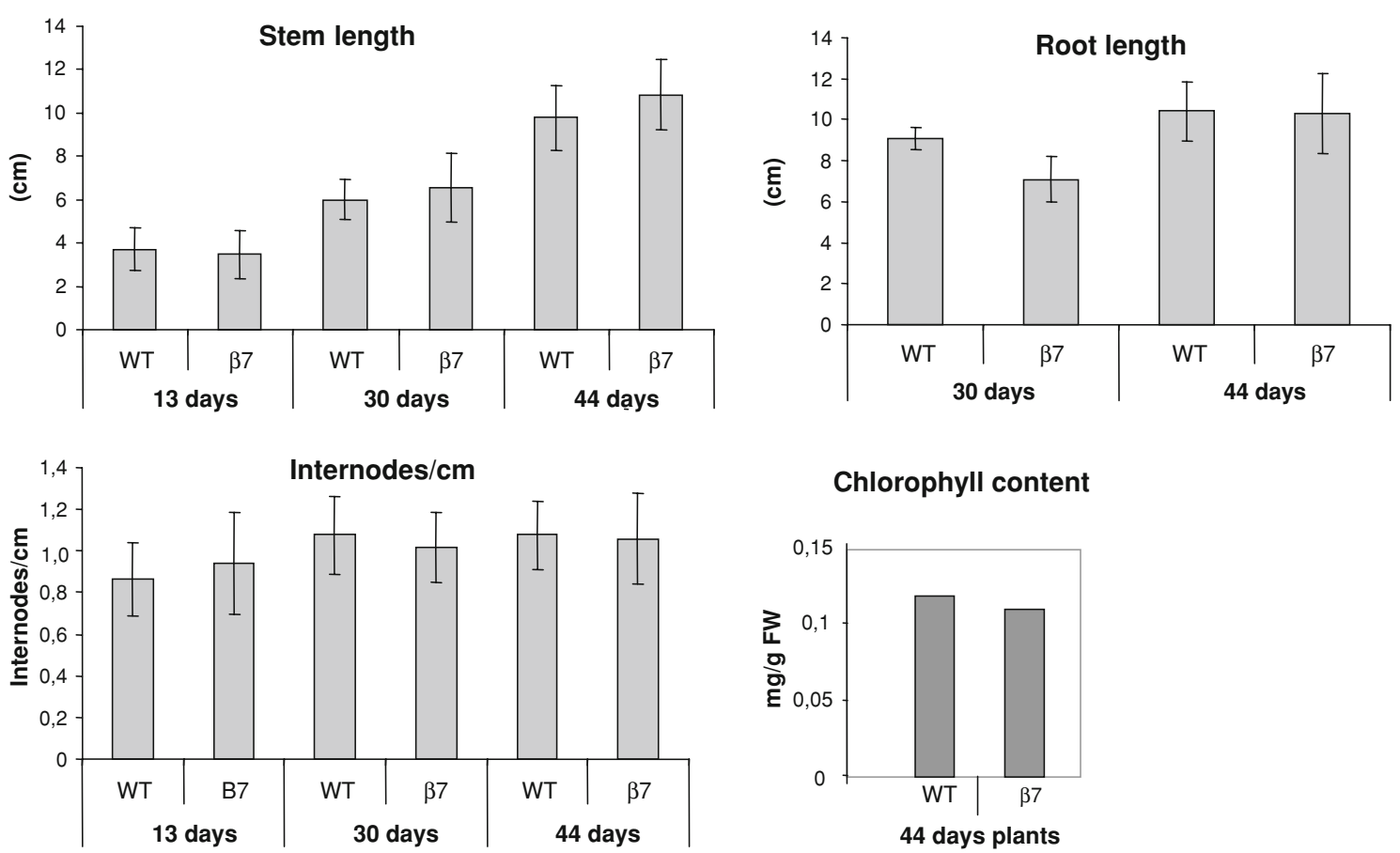

Chlorophyll content

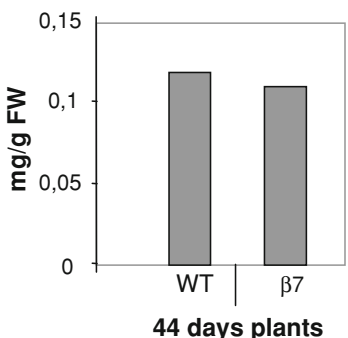

Fig. 6 Morphological characteristics of wild type and $\beta 7$ plants. Plants were grown under multiplication conditions for 13,30 or 44 days. Stem length $(\mathrm{cm})$, root length $(\mathrm{cm})$, number of internodes $($ per $\mathrm{cm})$ and chlorophyll content $\left(\mathrm{mg} \mathrm{g}^{-1} \mathrm{FW}\right.$, fresh weight) was determined

Table 3 Effect of sucrose $(8 \%)$, CCC $\left(0.5 \mathrm{mg} \mathrm{ml}^{-1}\right)$ or GA3 $(0.5 \mu \mathrm{M})$ on tuber induction

\begin{tabular}{|c|c|c|c|c|c|c|c|c|c|}
\hline \multicolumn{5}{|l|}{ WT } & \multicolumn{5}{|l|}{$\beta 7$} \\
\hline $\begin{array}{l}\text { Days in } \\
8 \% \text { SUC }\end{array}$ & $n$ & NIS & IS & $\begin{array}{l}\% \text { of tuber } \\
\text { induction }\end{array}$ & $\begin{array}{l}\text { Days in } \\
8 \% \text { SUC }\end{array}$ & $n$ & NIS & IS & $\begin{array}{l}\% \text { of tuber } \\
\text { induction }\end{array}$ \\
\hline 8 & 31 & 13 & 18 & 58 & 8 & 32 & 12 & 20 & 62.5 \\
\hline 10 & 36 & 18 & 18 & 50 & 10 & 36 & 1 & 35 & 97.2 \\
\hline 24 & 30 & 14 & 16 & 53 & 24 & 39 & 4 & 35 & 90 \\
\hline Total & 97 & 45 & 52 & 53.6 & Total & 107 & 17 & 90 & 84 \\
\hline $\begin{array}{l}\text { Days in } 8 \% \\
\text { SUC+CCC }\end{array}$ & $n$ & NIS & IS & $\begin{array}{l}\% \text { of tuber } \\
\text { induction }\end{array}$ & $\begin{array}{l}\text { Days in } 8 \% \\
\text { SUC+CCC }\end{array}$ & $n$ & NIS & IS & $\begin{array}{l}\% \text { of tuber } \\
\text { induction }\end{array}$ \\
\hline 10 & 17 & 0 & 17 & 100 & 10 & 18 & 0 & 18 & 100 \\
\hline 24 & 15 & 0 & 15 & 100 & 24 & 20 & 0 & 20 & 100 \\
\hline Total & 32 & 0 & 32 & 100 & Total & 38 & 0 & 38 & 100 \\
\hline $\begin{array}{l}\text { Days in } 8 \% \\
\text { SUC+GA3 }\end{array}$ & $n$ & NIS & IS & $\begin{array}{l}\% \text { of tuber } \\
\text { induction }\end{array}$ & $\begin{array}{l}\text { Days in } 8 \% \\
\text { SUC+GA3 }\end{array}$ & $n$ & NIS & IS & $\begin{array}{l}\% \text { of tuber } \\
\text { induction }\end{array}$ \\
\hline 10 & 16 & 16 & 0 & 0 & 10 & 14 & 14 & 0 & 0 \\
\hline 15 & 21 & 21 & 0 & 0 & 15 & 30 & 22 & 0 & 0 \\
\hline Total & 37 & 37 & 0 & 0 & Total & 44 & 36 & 0 & 0 \\
\hline
\end{tabular}

the highest increase (almost 4-fold); which could be related to a synergistic effect of sucrose and ABA. However no induction in response to phytohormones was observed in the $\beta 7$ line (Fig. 9A, right panel).

Previous reports have proposed that CDPKs could participate in the GA transduction pathway (Abo-el-Saad and
Wu 1995; Khan et al. 2005; Zhang et al. 2005). Therefore, StCDPK1 expression was studied in wild type cuttings incubated during 10 days in tuber induction conditions $(8 \%$ sucrose, complete darkness) but with the presence of GA3; and in cuttings grown during 13 days in tuber inducing conditions that were then transferred for 2 or $6 \mathrm{~h}$ to liquid 

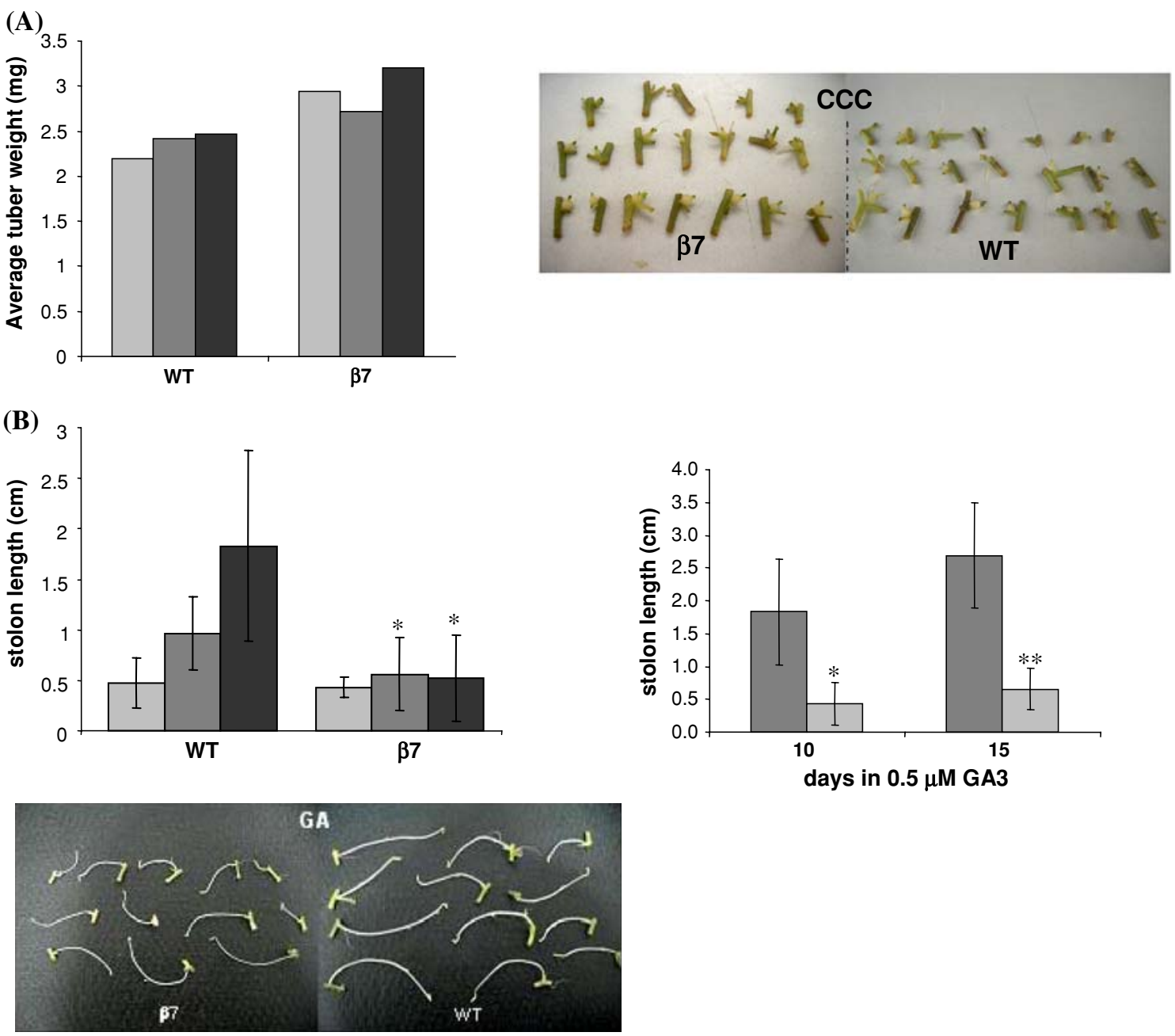

Fig. 7 Differential responses of wild type and $\beta 7$ stem cuttings grown under tuberization conditions to: (A) the addition of CCC (inhibitor of GA synthesis); (B) the addition of 0.05-0.5 $\mu \mathrm{M}$ GA3. A Average weight $(\mathrm{mg})$ of wild type and $\beta 7$ microtubers from stem cuttings treated or not (Control = light grey bars) with 0.05 (dark grey bars) or $0.5 \mathrm{mg} \mathrm{ml}^{-1}$ (black bars) CCC (left panel). Photographs of CCC-treated wild type (WT) and $\beta 7$ microtubers (right panel). B Wild type $(n=20)$ and $\beta 7(n=20)$ stem cuttings were cultured during 10 days with different GA3 concentrations and stolon length

Table 4 Effect of increasing sucrose concentrations on tuber yield and stolon length

\begin{tabular}{llllllll}
\hline $\begin{array}{l}\text { Sucrose in the } \\
\text { culture media }\end{array}$ & \multicolumn{2}{l}{ Tuber yield } & \multicolumn{5}{l}{ Length of stolons $(\mathrm{cm})$} \\
\cline { 2 - 3 } \cline { 6 - 7 } & $\beta 7$ & WT & & $\beta 7$ & $n$ & WT & $n$ \\
\hline $2 \%$ & $0 / 23$ & $0 / 22$ & & $2.7 \pm 0.2$ & 23 & $2.5 \pm 0.2$ & 22 \\
$4 \%$ & $0 / 25$ & $0 / 26$ & & $2.4 \pm 0.15$ & 25 & $2.7 \pm 0.2$ & 26 \\
$6 \%$ & $6 / 31$ & $0 / 29$ & $2 \pm 0.1$ & 31 & $1.5 \pm 0.3$ & 29 \\
$8 \%$ & $18 / 18$ & $9 / 16$ & & $0.75 \pm 0.25$ & 18 & $1.5 \pm 0.1$ & 16 \\
\hline
\end{tabular}

MS media with $8 \%$ sucrose with or without (control) $0.5 \mu \mathrm{M}$ GA3. For the long treatment, wild type cuttings treated during 10 days with $8 \%$ sucrose were used as (cm) was determined (left panel). Controls without GA treatment (light grey bars; $n=8$ ); dark grey bars indicate $0.05 \mu \mathrm{M}$ GA and black bars indicate $0.5 \mu \mathrm{M}$ GA treatments. Asterisk indicates that the result is statistically significant $(P<0.01)$. Wild type (dark grey) and $\beta 7$ (light grey) stem cuttings were cultured during 10 or 15 days with $0.5 \mu \mathrm{M}$ GA3 and stolon length $(\mathrm{cm})$ was determined (right panel). Asterisk indicates that the result is statistically significant $(P=0.0192$; ** $P=0.008)$. Photographs of GA3-treated wild type (WT) and $\beta 7$ stolons (lower panel)

controls. No induced stolons were present in the long treatment with GA. A 50\% increase in StCDPK1 expression was observed in response to the long treatment (data not shown), confirming the enhancement previously observed.

The expression of StCDPK1, StCDPK3 and of two enzymes involved in the GA-biosynthetic pathway, GA2oxidase and GA20-oxidase, was determined in the short treatment. Data are shown relative to expression of ubiquitin and in all cases controls ( $8 \%$ sucrose) are set as 1 (Fig. 9B). The GA20-oxidase in general, leads to the formation of a C19-GA which after 3-oxidation produces active $\mathrm{GA}\left(\mathrm{GA}_{4}\right.$ and $\left.\mathrm{GA}_{1}\right)$. These bioactive products are subsequently inactivated by 2 -oxidation catalysed by GA 


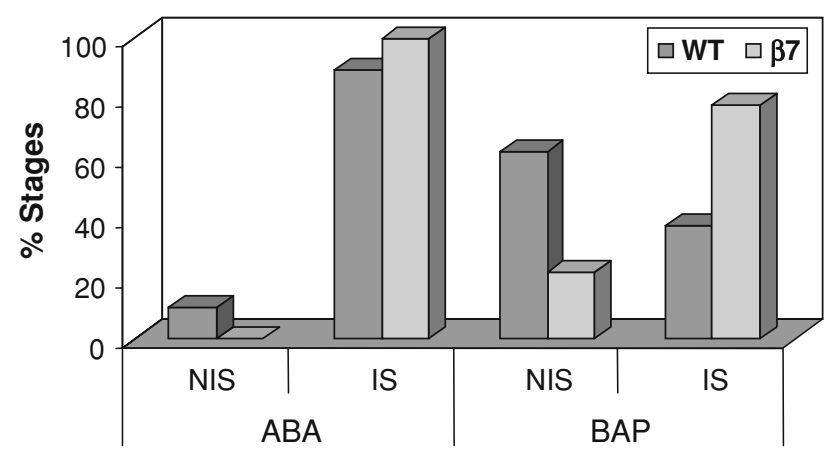

Fig. 8 Responses of wild type and $\beta 7$ stem cuttings grown under tuberization conditions to the addition of ABA and BAP. Percentage $(\%)$ of induced (IS) or non-induced stolons (NIS) was determined in wild type (WT, dark grey) and $\beta 7$ (light grey) internodes treated with 7.6 $\mu \mathrm{M} \mathrm{ABA}$ or $5 \mathrm{mg} \mathrm{ml}^{-1} \mathrm{BAP}$

2-oxidase. A $50 \%$ increase in GA2-oxidase expression levels was observed after $2 \mathrm{~h}$ of treatment with GA3 in accordance to a positive feed-back, but after $6 \mathrm{~h}$ of treatment, GA2-oxidase expression returns to control levels. Regarding the expression of GA20-oxidase, a gradual increase was observed after the treatment. An almost 3-fold increase in StCDPK1 expression was observed in the induced stolons exposed to GA for $2 \mathrm{~h}$. After $6 \mathrm{~h}$ exposure, StCDPK 1 expression returned to basal levels. In contrast to
StCDPK1 expression, StCDPK3 was not induced by GA3, moreover it was downregulated after $6 \mathrm{~h}$ of treatment. Altogether, these results suggest that StCDPK1 could be involved in GA signalling upon tuber development.

\section{Discussion}

In this manuscript we describe for the first time the genomic organization of a CDPK gene in Solanum tuberosum, and the response of wild type plants and of a transgenic line with low StCDPK1 expression to different tuberization conditions. StCDPK1 is transiently expressed in swelling stolons (Raices et al. 2001) and the increase (5-fold) in StCDPK1 protein observed in induced stolons confirms that it is developmentally regulated.

Based upon sequence homology CDPKs can be classified into four major subgroups (Cheng et al. 2002), though the significance of these subgroups with regard to biochemical or physiological function is not known (Hrabak et al. 2003). StCDPK1 coding sequence is similar to Arabidopsis and rice CDPKs (AtCPK9, 80\%, AtCPK33, 78\%, OsCPK19, 79\%) belonging to subgroup IIa. Its genomic structure was found to be identical to these genes. According to Li et al. (2008), CDPK genes belonging to the
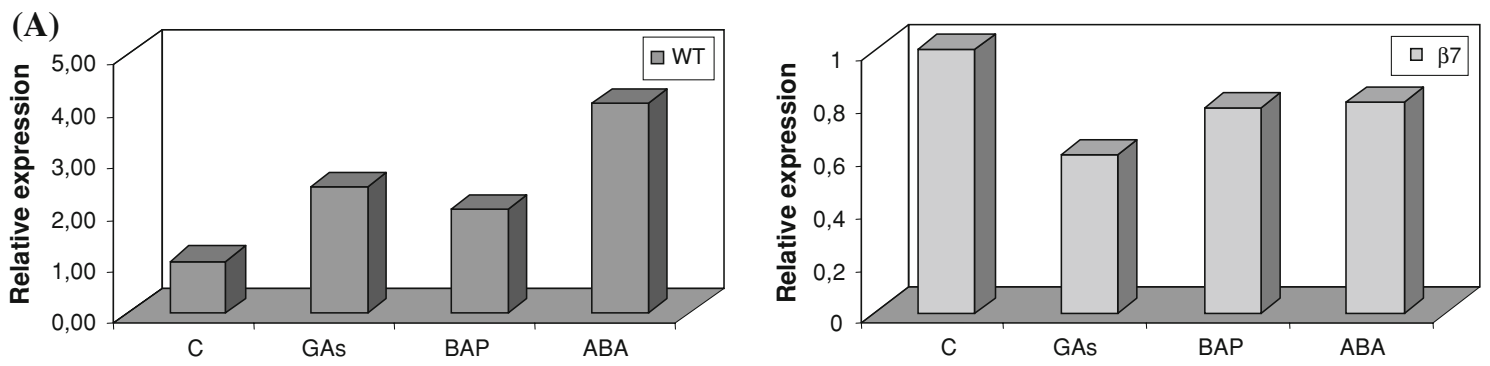

(B)

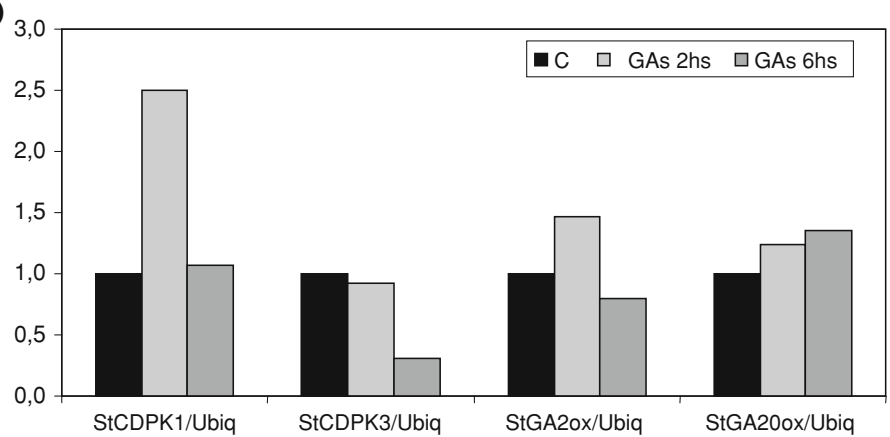

Fig. 9 Relative expression of $S t C D P K 1$ in: A Wild type (right panel) and $\beta 7$ (left panel) plants grown during 10 days (long treatment) under tuberization conditions ( $8 \%$ sucrose, complete darkness) with the addition of phytohormones (GA, BAP and ABA). StCDPK1 expression was normalized to Ubiquitin expression. In both cases, the expression in control conditions ( $8 \%$ sucrose) was set as 1 . B Wild type plants grown during 13 days under tuberization conditions (8\% sucrose, complete darkness) and transferred to liquid MS media with $8 \%$ sucrose (control, black) or $8 \%$ sucrose $+\mathrm{GA} 3$ during 2 (light grey) or 6 (dark grey) hours (short treatments). In addition, the expression of GA2-ox and GA20-ox was determined in the short treatments. The expression of StCDPK1, GA2-ox and GA20-ox was normalized to Ubiquitin expression. The expression in control conditions $(8 \%$ sucrose) was set as 1 
same group had the same number of introns among wheat, rice and Arabidopsis. This is also true for StCDPKl, therefore not only the coding sequence but also the gene structure can be considered a characteristic shared by the group. Introns are inserted in nearly the same position in all these genes, however, there is a considerable variation in the size of the corresponding introns, some being very large, as is the case of StCDPK1. Though genome size may not necessarily be correlated with intron size, this could be one of the factors that influence the size of the potato genome (about $840 \mathrm{Mb}$ ).

Our mapping experiments indicate that StCDPKl is localized in the distal arm of chromosome 12. The fact that intronic sequences were used in these experiments guarantees that we have mapped this gene and not another member of the CDPK family. In Arabidopsis, wheat and rice genomes CDPKs are distributed in all chromosomes. Interestingly, in Arabidopsis, a gene cluster on the short arm of chromosome IV contains five genes (AtCPK 21, 22, 23,27 , and 31 ), all members of subgroup IIa. It would be interesting to determine if a similar organization is observed in the potato genome.

Modification with lipophilic moieties has been described as an important mechanism involved in membrane anchoring of cytoplasmic proteins, which tightly regulates their proper intracellular targeting (Gonzalo and Linder 1998; Smotrys and Linder 2004). In the majority of the cases studied to date, dually acylated proteins are regulated through a palmitoylation-depalmitoylation cycle. Our previous results indicated that StCDPK1 had a functional myristoylation and palmitoylation consensus and StCDPK1::GFP fusion protein was found to be associated with plasma membranes when expressed in onion epidermal cells (Raices et al. 2003a). Experiments performed with an artificial protein showed that association to the plasma membrane was only observed in dually acylated constructs (Navarro-Lérida et al. 2002). Western blot experiments show that StCDPK1 is mainly associated to the microsomal fraction of swelling stolons or to a PM-rich fraction purified from sprouting tubers that displays higher CDPK activity than soluble fractions (4-fold). The antiStCDPK1 antibody detected a positive signal in the periphery of the cells from the periderm and neighbouring parenchyma tissues of swelling stolons. Moreover, TEM analysis of swelling stolons indicates that StCDPK1 is located in the site corresponding to the plasma membrane of parenchyma cells. These results are consistent with in situ hybridization experiments showing that the StCDPKI mRNA was abundant in external cells of swelling stolons (Raices et al. 2003b). Altogether our results indicate that in vivo this kinase is targeted to the plasma membrane.

While $C D P K$ genes and the proteins they encode have been identified in many species, the studies to clarify their roles in plant growth and development are still under way. Different approaches are being used to investigate the functions of these proteins but these experiments can be complicated by the existence of multiple, closely related genes that may have similar functions. Knockouts in these kinase genes usually have not had an obvious phenotype, indicating either that the correct conditions to identify a phenotype were not tested or that the protein's function can be fulfilled by other related family members (Hrabak et al. 2003). In an effort to elucidate the role of StCDPK1 in tuber formation, transgenic lines with reduced expression of StCDPK1 ( $\beta 7$ ) were produced. These lines did not differ from controls when cultured under multiplication conditions, however when grown under tuber inducing conditions some significant differences were observed. Most important is that the $\beta 7$ line tuberized earlier than controls without the addition of CCC (GA inhibitor), developed more tubers than wild type plants in the presence of hormones that promote tuberization in potato (ABA and BAP) and was more insensitive to GA action (stolons were significantly shorter than those of control plants).

Potato plants tuberize in response to endogenous growth regulators that reflect changing environmental conditions. According to the classical hypothesis, a substance is synthesized in the leaves under short-day conditions and transported to the stolons, where it triggers tuber formation (Struik et al. 1987). The exact nature of this transmissible signal is still unknown but it is most likely based on a mixture of both inducing and inhibiting types of signals (Ewing and Struik 1992; Jackson 1999; Martinez-Garcia et al. 2002). Two pathways regulate tuberization; one is photoperiod-dependent and the other is GAs-dependent. Both pathways are coordinated and are necessary to direct this developmental process (Martínez-García et al. 2002). During the early stages of the process, GAs regulate the production and transport of the tuberizing signal, and in the later stages they modulate the late responses. Therefore, high GAs concentrations in the aerial portion of the plant determine the morphological changes while low GAs concentrations in the stolon tips allow tuber formation $(\mathrm{Xu}$ et al. 1998). Whether biologically active GAs are part of the transmissible signal or play a role in the production, sensitivity or transport of the tuberization-promoting or inhibiting signals within the plant remains to be resolved.

Considerable progress has been made in understanding the pathways involved in GA biosynthesis and metabolism. Catabolism of GAs is an important factor that regulates the endogenous levels of bioactive GAs. Bioactive GAs are $2 \beta$-hydroxylated to produce biologically inactive GAs, a step catalyzed by GA2-oxidase (Ross et al. 1995). StGA2oxl is upregulated during the early stages of potato tuber development prior to visible swelling and is 
predominantly expressed in the subapical region of the stolon and growing tuber, thus a role for StGA2ox 1 in early tuber initiation has been suggested. On the contrary, the transcript levels of StGA3ox2, an enzyme that catalyses the final step in the biosynthesis of bioactive GAs, is strongly downregulated at tuber onset (Kloosterman et al. 2007). The expression of GA2-oxidase genes from Arabidopsis was stimulated by the application of GA3 indicating a feedback regulation of these genes in order to maintain endogenous levels of bioactive GAs (Thomas et al. 1999). The increase in StGA2-ox expression observed after GA3 application (Fig. 9B) suggests that the potato gene is tightly regulated.

The GA signalling pathway essentially consists of three interacting players. GA receptors of rice (GID1) and Arabidopsis (Ueguchi-Tanaka et al. 2005; Nakajima et al. 2006) are able to interact, in a GA dependent way, with the DELLA proteins; these interactions solely depend on the presence of the DELLA-domain (Willige et al. 2007). DELLA proteins are inhibitors of GA responses, which are broken down in the presence of GAs, and this degradation is mediated by an E3 ligase, that is specified by an F-box protein such as SLY1 in Arabidopsis or GID2 in rice (McGinnis et al. 2003; Sasaki et al. 2003; Dill et al. 2004). In Arabidopsis thaliana, once DELLA proteins are destabilized, the nuclear transcription factor PIF4 accumulates in the nucleus and controls genes mediating cell elongation (de Lucas et al. 2008).

Protein kinases and protein phosphorylation have been shown to play an important role in the GA response. Typically; specific phosphorylation of target sequences is required for efficient F-box-mediated recruitment of target proteins to SCF E3 ubiquitin ligase complexes (Patton et al. 1998; Jackson and Eldridge 2002; Busino et al. 2003). Fu et al. (2004) suggest that the inherent (phosphorylationindependent) level of interaction between the DELLA and SLY1 proteins is further strengthened by phosphorylation. DELLA proteins are now known to be fundamental to the regulation of growth via several plant developmental regulatory pathways and are thought to serve as integrators of multiple growth regulatory signalling inputs (Achard et al. 2003; Fu and Harberd 2003).

It has been well documented that CDPK participate in early signal transduction and function as integration points for multiple stimuli (Cheng et al. 2002; Ludwig et al. 2004). The GA3-induced increase in $\mathrm{Ca}^{2+}$ influx observed in barley aleurone protoplasts (Gilroy and Jones 1992), provides a possible mechanism to link the GA3 response with activation of CDPKs. HvCDPK1 mediates the GA response of the aleurone through regulation of vacuolar function that lies downstream of transcriptional regulation (McCubbin et al. 2004). In rice, evidences that CDPKs are involved in the GA response pathway accumulate: the activity of a plasma membrane CDPK in GA-treated rice seeds was higher than in untreated seeds (Abo-El-Saad and Wu 1995); CDPK activity also increased in rice leaves after GA treatment and the phosphorylation of seven proteins was enhanced by this treatment (Khan et al. 2005). CDPK and phosphorylation activities of some proteins were increased in the Rubisco activase sense transgenic rice plants by GA3-treatment (Sharma and Komatsu 2002). Antisense OsCDPK13 transgenic rice lines were shorter than the vector control lines, and the expression of OsCDPK13 was lower in dwarf mutants of rice than in wild type. This rice isoform became phosphorylated in response to cold and GA and its expression and protein accumulation were up-regulated by GA3 treatment (Abbasi et al. 2004). In addition, the expression of two tobacco CDPK isoforms, NtCDPK1 (Yoon et al. 1999) and NtCPK4 (Zhang et al. 2005) and of IiCDPK2, a CDPK gene from Isatis indigotica, was enhanced in response to GAs ( $\mathrm{Lu}$ et al. 2006). In this paper we show that GA-treatments enhanced StCDPK1 expression. The fact that, in vitro, $\beta 7$ plants tuberized earlier and, when exposed to GAs $\beta 7$ stolons were shorter than wild types, together with the increase observed in $S t C D P K 1$ expression in response to GAs suggests that this CDPK isoform could modulate GA signalling.

However, StCDPKI expression was also positively modulated by tuberization-promoting phytohormones (ABA and BAP) and by sucrose (Raices et al. 2003b). At the protein level, a CDPK activity increased in sucrosetreated potato plants (Raices et al. 2003c) while StCDPK1 protein content increased (1.5- to 2.5-fold) in potato stolons in response to sucrose. ABA and sucrose promote accumulation of storage reserves in developing plant embryos (reviewed in Gibson 2004), and in potato stolons both stimulate tuberization. ABA functions as an antagonist of GAs, and sucrose regulates tuber formation by changing the GA level of the developing stolons and tubers (Xu et al. 1998a). Calcium is involved in ABA signal transduction (reviewed in Finkelstein et al. 2002; Himmelbach et al. 2003; Fan et al. 2004) and several Arabidopsis CDPK isoforms are involved in this response (Mori et al. 2006; Zhu et al. 2007). According to the expression data observed in wild type plants, it can be suggested that StCDPK1 could be a target of $\mathrm{ABA}$ action and that both $\mathrm{ABA}$ and sugar have a synergistic effect on the kinase expression.

Under in vitro conditions the time point of tuber formation appears to rely primarily on sucrose/GA interactions within the stolon tip (Xu et al. 1998) whilst under in vivo conditions additional regulatory factors are required to induce tuber formation. Sugar- and phytohormone-response pathways exhibit 'crosstalk' in the regulation of many processes. Our results suggest that StCDPK1 may act as a stimulus-response coupler in 
calcium-regulated processes during potato tuberization. Under non-inducing conditions, GA inhibition prevails; stolons elongate and no swelling is observed. In our culture conditions GA inhibitory effect is stronger than the sucrose promoting effect because in the presence of $0.5 \mu \mathrm{M}$ GA3 no swelling is observed. According to the results obtained with the $\beta 7$ line, StCDPK1 could be a positive regulator of the elongation response and a negative regulator of the tuberization process. In another developmental process, the formation of root nodules as result of the Medicago-Rhizobia interaction, a CDPK isoform, MtCPK3, acted as a negative regulator that controlled nodule number (Gargantini et al. 2006). Under inducing conditions, the relative balance of inducers and inhibitors of tuberization promotes stolon to tuber transition, elongation ceases and stolon swelling begins. StCDPK1 could also be involved in this process in view of the rise in transcript (Raices et al. 2003a, b, c) and protein levels (Fig. 4) observed in response to increasing sucrose concentrations (4-8\%) and to the high expression of StCDPK1 detected in swelling stolons.

In both conditions (inhibiting or promoting), once cytosolic calcium has raised StCDPK1 could phosphorylate a response element and thus stimulate or inhibit an event or process. In the future, identifying the kinase substrate/s will help to elucidate this signalling pathway. A potato CDPK isoform, StCDPK5, induces the phosphorylation of StRBOHB and regulates the oxidative burst (Kobayashi et al. 2007). Recently it was shown that superoxide anion acts as a signal transducer via GA biosynthetic pathways for the regulation of plant growth and tuber development of potato (Kim et al. 2007). Thus, the possibility of a crosstalk with an oxidative burst-mediated redox signalling pathway during tuberization should be considered.

Other CDPK isoforms were shown to be modulated by different phytohormones. NtCDPK1 from tobacco is induced by GA, ABA and cytokinin (Yoon et al. 1999), it phosphorylates a regulatory subunit of the $26 \mathrm{~S}$ proteasome of tobacco in vitro, and interacts with it in vivo (Lee et al. 2003). More recent studies showed that NtCDPK1 plays a role in lateral root development and root elongation (Lee et al. 2006). In Arabidopsis, AtCPK30 encodes a CDPK that is highly expressed in roots and is induced by $A B A$, IAA, 2,4-D, GA(3) and 6-BA treatments (Yuan et al. 2007). The fact that a $C D P K$ gene can be induced by different hormones could suggest that the gene expression profile is not the central part of the regulation of CDPKs. Changes in the level of cytoplasmic $\mathrm{Ca}^{2+}$ or in the phosphorylation/dephosphorylation status of CDPK substrates could be important in the regulation of CDPK activity. Recently, the expression patterns of wheat CDPKs were analyzed under various conditions. Each CDPK isoform exhibited responses to multiple stress treatments, suggesting that they were major converging points for crosstalk between different signal transduction pathways. On the other hand, multiple CDPKs seemed to be necessary to coordinate with one stress stimulus ( $\mathrm{Li}$ et al. 2008). In particular, StCDPK1 expression was induced by different hormones that are related to the tuberization process. Our results suggest that StCDPK1 could be a converging point for the inhibitory and promoting signals that influence the onset of potato tuberization.

Acknowledgments We thank Dr S. Prat Monguío (CSIC, Spain) for the Ga2-oxidase and the GA20-oxidase clones and Dr Mark Taylor for the Solanum tuberosum var. Desiree genomic library. This work was supported by grants from the Consejo Nacional de Investigaciones Científicas y Técnicas (CONICET), the University of Buenos Aires, Argentina and the Agencia Nacional de Promoción Científica y Tecnológica (FONCYT-ANPCYT) and the USDA-SCRP-FAS project: A biotechnology tool to broaden the genetic base of potato in a cooperative framework. We thank the technical work of Silvina Divito (INTA, Balcarce). RMU and SM are members of the National Research Council, CONICET. PRG, VG and CG are fellows from CONICET.

\section{References}

Abbasi F, Onodera H, Toki S, Tanaka H, Komatsu S (2004) OsCDPK13, a calcium-dependent protein kinase gene from rice, is induced by cold and gibberellin in rice leaf sheath. Plant Mol Biol 55:541-552. doi:10.1007/s11103-004-1178-y

Abo-el-Saad M, Wu R (1995) A rice membrane calcium-dependent protein kinase is induced by gibberellin. Plant Physiol 108:787793. doi:10.1104/pp.108.2.787

Achard P, Vriezen WH, Van Der Straeten D, Harberd NP (2003) Ethylene regulates Arabidopsis development via the modulation of DELLA protein growth repressor function. Plant Cell 15:2816-2825. doi:10.1105/tpc.015685

Asano T, Tanaka N, Yang G, Hayashi N, Komatsu S (2005) Genomewide identification of the rice calcium-dependent protein kinase and its closely related kinase gene families: comprehensive analysis of the CDPKs gene family in rice. Plant Cell Physiol 46:356-366. doi:10.1093/pcp/pci035

Bachmann M, Shiraishi N, Campbell WH, Yoo BC, Harmon AC, Huber SC (1996) Identification of the major regulatory phosphorylation site as Ser-543 in spinach leaf nitrate reductase and its phosphorylation by a calcium-dependent protein kinase in vitro. Plant Cell 8:505-517

Balamani V, Veluthambi K, Poovaiah BW (1986) Effect of calcium on tuberization in potato. Plant Physiol 80:856-858

Bonierbale MW, Plaisted RL, Pineda O, Tanksley SD (1994) QTL analysis of trichome-mediated insect resistance in potato. Theor Appl Genet 87:973-987. doi:10.1007/BF00225792

Busino L, Donzelli M, Chiesa M, Guardavaccaro D, Ganoth D, Dorello NV, Hershko A, Pagano M, Draetta GF (2003) Degradation of Cdc25A by b-TrCP during $\mathrm{S}$ phase and in response to DNA damage. Nature 426:87-91. doi:10.1038/nature02082

Carrera E, Bou J, Garcia-Martinez JL, Prat S (2000) Changes in GA 20-oxidase gene expression strongly affect stem length, tuber induction and tuber yield of potato plants. Plant J 22:247-256. doi:10.1046/j.1365-313x.2000.00736.x

Cheng S-H, Willmann MR, Chen H-C, Sheen J (2002) Calcium signaling through protein kinases. The Arabidopsis calciumdependent protein kinase gene family. Plant Physiol 129:469485. doi:10.1104/pp.005645 
Cutter EG (1978) Structure and development of the potato plant. In: Harris PM (ed) The potato crop. Halsted Press, Wiley, New York, pp 70-152

de Lucas M, Davière JM, Rodríguez-Falcón M, Pontin M, IglesiasPedraz JM, Lorrain S, Fankhauser C, Blázquez MA, Titarenko E, Prat S (2008) A molecular framework for light and gibberellin control of cell elongation. Nature 451:480-484. doi:10.1038/ nature 06520

Dill A, Thomas SG, Hu J, Steber CM, Sun TP (2004) The Arabidopsis Fbox protein SLEEPY1 targets gibberellin signaling repressors for gibberellin-induced degradation. Plant Cell 16:1392-1405. doi: $10.1105 /$ tpc. 020958

Evans NH, McAinsh MR, Hetherington AM (2001) Calcium oscillations in higher plants. Curr Opin Plant Biol 4:415-420. doi: 10.1016/S1369-5266(00)00194-1

Ewing EE, Struik PC (1992) Tuber formation in potato: induction, initiation and growth. Hortic Rev (Am Soc Hortic Sci) 14:89-197

Fan LM, Zhao ZX, Assmann SM (2004) Guard cells: a dynamic signaling model. Curr Opin Plant Biol 7:537-546. doi:10.1016/ j.pbi.2004.07.009

Feingold SE, Lloyd J, Norero N, Bonierbale M, Lorenzen J (2005) Map location and diversity values for new potato SSRs developed from EST databases. Theor Appl Genet 111:456466. doi:10.1007/s00122-005-2028-2

Fernie AR, Willmitzer L (2001) Molecular and biochemical triggers of potato tuber development. Plant Physiol 127:1459-1465. doi: 10.1104/pp.010764

Finkelstein RR, Gampala S, Rock C (2002) Abscisic acid signaling in seeds and seedlings. Plant Cell 14:S15-S45

Fiske CH, Subbarow Y (1925) The colorimetric determination of phosphorus. J Biol Chem 66:375

Fu X, Harberd NP (2003) Auxin promotes Arabidopsis root growth by modulating gibberellin response. Nature 421:740-743. doi: 10.1038/nature01387

Fu X, Richards DE, Fleck B, Xie D, Burton N, Harberd NP (2004) The Arabidopsis Mutant sleepylgar ${ }^{2-1}$ protein promotes plant growth by increasing the affinity of the $\mathrm{SCF}^{\mathrm{SLY} 1} \mathrm{E} 3$ ubiquitin ligase for DELLA protein substrates. Plant Cell 16:1406-1418. doi: $10.1105 /$ tpc. 021386

Furuichi T, Muto S (2005) $\mathrm{H}^{+}$-Coupled sugar transporter, an initiator of sugar-induced $\mathrm{Ca}^{2+}$-signaling in plant cells. Z Naturforsch 60:764-768

Gargantini P, Gonzalez-Rizzo S, Chinchilla D, Raices M, Giammaria V, Ulloa R, Frugier F, Crespi M (2006) A CDPK isoform regulates nodule number in Medicago truncatula. Plant $\mathbf{J}$ 48:843-856. doi:10.1111/j.1365-313X.2006.02910.x

Garner N, Blake J (1989) The induction and development of potato microtubers in vitro on media free of growth regulating substances. Ann Bot (Lond) 63:663-674

Gibson SI (2004) Sugar and phytohormone response pathways: navigating a signalling network. J Exp Bot 55:253-264. doi: 10.1093/jxb/erh048

Gilroy S, Jones RL (1992) Gibberellic acid and abscisic acid coordinately regulate cytoplasmic calcium and secretory activity in barley aleurone protoplasts. Proc Natl Acad Sci USA 89:3591-3595. doi:10.1073/pnas.89.8.3591

Gonzalo S, Linder ME (1998) SNAP-25 palmitoylation and plasma membrane targeting require a functional secretory pathway. Mol Biol Cell 9:585-597

Harmon AC (2003) Calcium-regulated protein kinases of plants. Gravit Space Biol Bull 16:83-90

Harris N (1994) Immunocytochemistry for light and electron microscopy. In: Harris S, Oparka KJ (eds) Plant cell biology. Oxford University Press, Oxford, pp 157-176
Himmelbach A, Yang Y, Grill E (2003) Relay and control of abscisic acid signaling. Curr Opin Plant Biol 6:470-479. doi: 10.1016/S1369-5266(03)00090-6

Hrabak EM, Chan CW, Gribskov M, Harper JF, Choi JH, Halford N, Kudla J, Luan S, Nimmo HG, Sussman MR, Thomas M, WalkerSimmons K, Zhu JK, Harmon AC (2003) The Arabidopsis CDPK-SnRK superfamily of protein kinases. Plant Physiol 132:666-680. doi:10.1104/pp.102.011999

Jackson SD (1999) Multiple signaling pathways controls tuber induction in potato. Plant Physiol 119:1-8. doi:10.1104/pp.119.1.1

Jackson PK, Eldridge AG (2002) The SCF ubiquitin ligase: an extended look. Mol Cell 9:923-925. doi:10.1016/S1097-2765 (02)00538-5

Khan MM, Jan A, Karibe H, Komatsu S (2005) Identification of phosphoproteins regulated by gibberellin in rice leaf sheath. Plant Mol Biol 58:27-40. doi:10.1007/s11103-005-4013-1

Kim MS, Kim HS, Kim YS, Baek KH, Oh HW, Hahn KW, Bae RN, Lee IJ, Joung H, Jeon JH (2007) Superoxide anion regulates plant growth and tuber development of potato. Plant Cell Rep 26:1717-1725. doi:10.1007/s00299-007-0380-1

Klimecka M, Muszyńska G (2007) Structure and functions of plant calcium-dependent protein kinases. Acta Biochim Pol 54:219-233

Kloosterman B, Navarro C, Bijsterbosch G, Lange T, Prat S, Visser RG, Bachem CW (2007) StGA2ox1 is induced prior to stolon swelling and controls GA levels during potato tuber development. Plant J 52:362-373. doi:10.1111/j.1365-313X.2007.03245.X

Kobayashi M, Ohura I, Kawakita K, Yokota N, Fujiwara M, Shimamoto K, Doke N, Yoshioka H (2007) Calcium-dependent protein kinases regulate the production of reactive oxygen species by potato NADPH oxidase. Plant Cell 19:1065-1080. doi: $10.1105 /$ tpc. 106.048884

Krauss A (1985) Interaction of nitrogen nutrition, phytohormones and tuberization. In: Li PH (ed) Potato physiology. Academic Press, London, pp 209-231

Larsson C, Sommarin M, Widell S (1994) Isolation of highly purified plant plasma membranes and separation of inside-out and rightside-out vesicles. Methods Enzymol 228:451-469. doi: 10.1016/0076-6879(94)28046-0

Lee SS, Cho HS, Yoon GM, Ahn J-W, Kim HH, Pai HS (2003) Interaction of NtCDPK1 calcium-dependent protein kinase with NtRpn3 regulatory subunit of the $26 \mathrm{~S}$ proteasome in Nicotiana tabacum. Plant J 33:825-840. doi:10.1046/j.1365-313X.2003.01672.x

Lee SS, Yoon GM, Rho EJ, Moon E, Pai H-S (2006) Functional characterization of NtCDPK1 in tobacco. Mol Cells 21:141-146

Li A-L, Zhu Y-F, Tan X-M, Wang X, Wei B, Guo H-Z, Zhang Z-L, Chen X-B, Zhao G-Y, Kong X-Y, Jia J-Z, Mao L (2008) Evolutionary and functional study of the CDPK gene family in wheat (Triticum aestivum L.). Plant Mol Biol 66:429-443. doi: 10.1007/s11103-007-9281-5

Lu SX, Hrabak EM (2002) An Arabidopsis calcium-dependent protein kinase is associated with the endoplasmic reticulum. Plant Physiol 128:1008-1021. doi:10.1104/pp.010770

Lu B, Ding R, Zhang L, Yu X, Huang B, Chen W (2006) Molecular cloning and characterization of a novel calcium-dependent protein kinase gene $I i C P K 2$ responsive to polyploidy from tetraploid Isatis indigotica. J Biochem Mol Biol 39:607-617

Ludwig AA, Romeis T, Jones JD (2004) CDPK-mediated signalling pathways: specificity and cross-talk. J Exp Bot 55:181-188. doi: 10.1093/jxb/erh008

MacIntosh GC, Ulloa RM, Raíces M, Téllez-Iñón MT (1996) Changes in calcium-dependent protein kinase activity during in vitro tuberization in potato. Plant Physiol 112:1541-1550

Martínez-García JF, Virgós-Soler A, Prat S (2002) Control of photoperiod-regulated tuberization in potato by the Arabidopsis 
flowering-time gene CONSTANS. Proc Natl Acad Sci USA 99:15211-15216. doi:10.1073/pnas.222390599

McCubbin AG, Ritchie SM, Swanson SJ, Gilroy S (2004) The calcium-dependent protein kinase HvCDPK1 mediates the gibberellic acid response of the barley aleurone through regulation of vacuolar function. Plant J 39:206-218. doi:10.1111/ j.1365-313X.2004.02121.x

McGinnis KM, Thomas SG, Soule JD, Strader LC, Zale JM, Sun TP, Steber CM (2003) The Arabidopsis SLEEPY1 gene encodes a putative F-box subunit of an SCF E3 ubiquitin ligase. Plant Cell 15:1120-1130. doi: $10.1105 /$ tpc. 010827

Menzel CM (1983) Tuberization in potato at high temperatures: gibberellin content and transport from buds. Ann Bot (Lond) 52:697-702

Menzel CM (1985) Tuberization in potato at high temperatures: interaction between temperature and irradiance. Ann Bot (Lond) 55:35-39

Mori IC, Murata Y, Yang Y, Munemasa S, Wang Y-F, Andreoli S, Tiriac H, Alonso JM, Harper JF, Ecker JR, Kwak JM, Schroeder JI (2006) CDPKs CPK6 and CPK3 function in ABA regulation of guard cell S-type anion- and $\mathrm{Ca}^{2+}$-permeable channels and stomatal closure. PLoS Biol 4:e327. doi:10.1371/journal.pbio. 0040327

Müller-Röber B, Sonnewald U, Willmitzer L (1992) Inhibition of the ADP-glucose pyrophosphorylase in transgenic potatoes leads to sugar-storing tubers and influences tuber formation and expression of tuber storage protein genes. EMBO J 11:1229-1238

Murashige T, Skoog F (1962) A revised medium for rapid growth and bio assays with tobacco tissue cultures. Physiol Plant 15:473497. doi:10.1111/j.1399-3054.1962.tb08052.x

Murray MG, Thompson WF (1980) Rapid isolation of high molecular weight plant DNA. Nucleic Acids Res 8:4321-4325. doi: 10.1093/nar/8.19.4321

Nakajima M, Shimada A, Takashi Y, Kim YC, Park SH, UeguchiTanaka M, Suzuki H, Katoh E, Iuchi S, Kobayashi M, Maeda T, Matsuoka M, Yamaguchi I (2006) Identification and characterization of Arabidopsis gibberellin receptors. Plant J 46:880-889. doi:10.1111/j.1365-313X.2006.02748.x

Navarro-Lérida I, Alvarez-Barrientos A, Gavilanes F, RodriguezCrespo I (2002) Distance-dependent cellular palmitoylation of de-novo-designed sequences and their translocation to plasma membrane subdomains. J Cell Sci 115:3119-3130

Patton EE, Willems AR, Tyers M (1998) Combinatorial control in ubiquitin-dependent proteolysis: don't Skp the F-box hypothesis. Trends Genet 14:236-243. doi:10.1016/S0168-9525(98)01473-5

Perl A, Aviv D, Galun E (1991) Nuclear-organelle interaction in Solanum: interspecific hybridizations and their correlation with a plastome dendrogram. Mol Gen Genet 228:193-200

Prat S, Frommer WB, Hofgen R, Keil M, Kossmann J, Koster-Topfer M, Liu XJ, Muller B, Peña-Cortés H, Rocha-Sosa M, SanchezSerrano JJ, Sonnewald U, Willmitzer L (1990) Gene expression during tuber development in potato plants. FEBS Lett 268:334338. doi:10.1016/0014-5793(90)81281-R

Raices M, Chico JM, Tellez-Iñón MT, Ulloa RM (2001) Molecular characterization of StCDPK1, a calcium-dependent protein kinase from Solanum tuberosum that is induced at the onset of tuber development. Plant Mol Biol 46:591-601. doi:10.1023/ A: 1010661304980

Raices M, Gargantini PR, Chinchilla D, Crespi M, Tellez-Iñón MT, Ulloa RM (2003a) Regulation of CDPK isoforms during tuber development. Plant Mol Biol 52:1011-1024. doi:10.1023/A: 1025478315648

Raices M, Ulloa RM, MacIntosh GC, Crespi M, Tellez-Iñón MT (2003b) StCDPK1 is expressed in potato stolon tips and is induced by high sucrose concentration. J Exp Bot 54:2589-2591. doi: $10.1093 / \mathrm{jxb} / \mathrm{erg} 282$
Raices M, MacIntosh GC, Ulloa RM, Gargantini PR, Vozza NF, Tellez-Iñón MT (2003c) Sucrose increases calcium-dependent protein kinase and phosphatase activities in potato plants. Cell Mol Biol 49:959-964

Ray S, Agarwal P, Arora R, Kapoor S, Tyagi AK (2007) Expression analysis of calcium-dependent protein kinase gene family during reproductive development and abiotic stress conditions in rice (Oryza sativa L. ssp. indica). Mol Genet Genomics 278:493505. doi:10.1007/s00438-007-0267-4

Rodríguez-Falcón M, Bou J, Prat S (2006) Seasonal control of tuberization in potato: conserved elements with the flowering response. Annu Rev Plant Biol 57:151-180. doi:10.1146/ annurev.arplant.57.032905.105224

Rosin FM, Hart JK, Horner HT, Davies PJ, Hannapel DJ (2003) Overexpression of a knox gene of potato alters vegetative development by decreasing gibberellin accumulation. Plant Physiol 132:106-111. doi:10.1104/pp.102.015560

Ross JJ, Reid JB, Swain SM, Hasan O, Poole AT, Hedden P, Willis CL (1995) Genetic regulation of gibberellin deactivation in Pisum. Plant J 7:513-523. doi:10.1046/j.1365-313X.1995.703 0513.x

Sarkar D (2008) The signal transduction pathways controlling in planta tuberization in potato: an emerging synthesis. Plant Cell Rep 27:1-8. doi:10.1007/s00299-007-0457-x

Sasaki A, Itoh H, Gomi K, Ueguchi-Tanaka M, Ishiyama K, Kobayashi M, Jeong DH, An G, Kitano H, Ashikari M, Matsuoka M (2003) Accumulation of phosphorylated repressor for gibberellin signaling in an F-box mutant. Science 299:18961898. doi: $10.1126 /$ science. 1081077

Shapiro MB, Senapathy P (1987) RNA splice junctions of different classes of eukaryotes; sequence statistics and functional implications in gene expression. Nucleic Acids Res 15:7155-7174. doi:10.1093/nar/15.17.7155

Sharma A, Komatsu S (2002) Involvement of a Ca(2+)-dependent protein kinase component downstream to the gibberellin-binding phosphoprotein, RuBisCO activase, in rice. Biochem Biophys Res Commun 290:690-695. doi:10.1006/bbrc.2001.6269

Simko I (1994) Sucrose application causes hormonal changes associated with potato tuber induction. J Plant Growth Regul 13:73-77. doi:10.1007/BF00210950

Smotrys JE, Linder ME (2004) Palmitoylation of intracellular signaling proteins: regulation and function. Annu Rev Biochem 73:559-587. doi:10.1146/annurev.biochem.73.011303.073954

Sonnewald U, Hajirezaei MR, Kossmann J, Heyer A, Trethewey RN, Willmitzer L (1997) Increased potato tuber size resulting from apoplastic expression of a yeast invertase. Nat Biotechnol 15: 794-797. doi:10.1038/nbt0897-794

Struik PC, Boon EJ, Vreugdenhil D (1987) Effects of extracellular extracts from leaves on the tuberization of cuttings of potato (Solanum tuberosum L.). Plant Physiol 84:214-217

Thomas SG, Phillips AL, Hedden P (1999) Molecular cloning and functional expression of gibberellin 2- oxidases, multifunctional enzymes involved in gibberellin deactivation. Proc Natl Acad Sci USA 96:4698-4703. doi:10.1073/pnas.96.8.4698

Ueguchi-Tanaka M, Ashikari M, Nakajima M, Itoh H, Katoh E, Kobayashi M, Chow TY, Hsing YI, Kitano H, Yamaguchi I, Matsuoka M (2005) Gibberellin insensitive dwarf1 encodes a soluble receptor for gibberellin. Nature 437:693-698. doi: 10.1038/nature04028

Visser RGF, Vreugdenhil D, Hendriks T, Jacobsen EJ (1994) Gene expression and carbohydrate content during stolon to tuber transition in potatoes (Solanum tuberosum). Physiol Plant 90:285-292. doi:10.1111/j.1399-3054.1994.tb00389.x

Vreugdenhil D, Sergeeva LI (1999) Gibberellins and tuberization in potato. Potato Res 42:471-481. doi:10.1007/BF02358163 
Willige BC, Ghosh S, Nill C, Zourelidou M, Dohmann EM, Maier A, Schwechheimer C (2007) The DELLA domain of GA INSENSITIVE mediates the interaction with the GA INSENSITIVE DWARF1A gibberellin receptor of Arabidopsis. Plant Cell 19:1209-1220. doi:10.1105/tpc.107.051441

Woolley DJ, Wareing PF (1972) Environmental effects on endogenous cytokinins and gibberellin levels in Solanum tuberosum. New Phytol 71:1015-1025. doi:10.1111/j.1469-8137.1972.tb01979.x

Xu X, van Lammeren AA, Vermeer E, Vreugdenhil D (1998) The role of gibberellin, abscisic acid, and sucrose in the regulation of potato tuber formation in vitro. Plant Physiol 117:575-584. doi: 10.1104/pp.117.2.575

Yoon GM, Cho HS, Ha HJ, Liu JR, Lee HP (1999) Characterization of NtCDPK1, a calcium-dependent protein kinase gene in
Nicotiana tabacum, and the activity of its encoded protein. Plant Mol Biol 39:991-1001. doi:10.1023/A:1006170512542

Yuan X, Deng KQ, Zhao XY, Wu XJ, Qin YZ, Tang DY, Liu XM (2007) A calcium-dependent protein kinase is involved in plant hormone signal transduction in Arabidopsis. J Plant Physiol Mol Biol 33:227-234

Zhang M, Liang S, Lu YT (2005) Cloning and functional characterization of $\mathrm{NtCPK} 4$, a new tobacco calcium-dependent protein kinase. Biochim Biophys Acta 1729:174-185

Zhu S-Y, Yu X-C, Wang X-J, Zhao R, Li Y, Fan R-C, Shang Y, Du S-Y, Wang X-F, Wu F-Q, Xu Y-H, Zhang X-Y, Zhang D-P (2007) Two calcium-dependent protein kinases, CPK4 and CPK11, regulate abscisic acid signal transduction in Arabidopsis. Plant Cell 19:3019-3036. doi:10.1105/tpc.107.050666 